\title{
Out of the shadows: Homebased workers organize for international recognition
}

Renana Jhabvala

Jane Tate

Follow this and additional works at: https://knowledgecommons.popcouncil.org/departments_sbsr-pgy

Part of the Family, Life Course, and Society Commons, Gender and Sexuality Commons, Inequality and Stratification Commons, International Public Health Commons, and the Work, Economy and Organizations Commons How does access to this work benefit you? Let us know!

\section{Recommended Citation}

Jhabvala, Renana and Jane Tate. 1996. "Out of the shadows: Homebased workers organize for international recognition," SEEDS no. 18. New York: Population Council. 


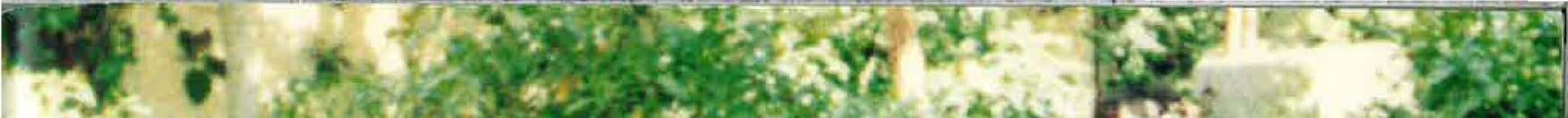

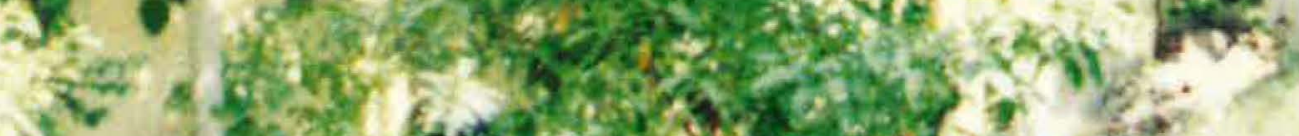

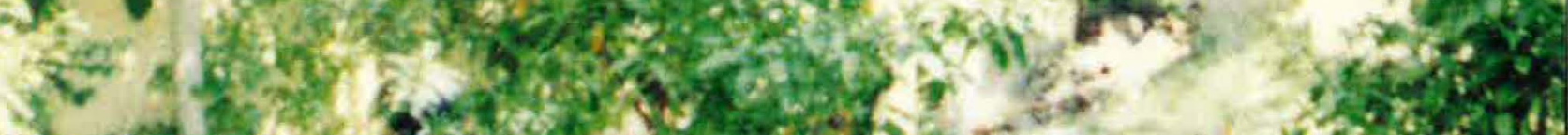

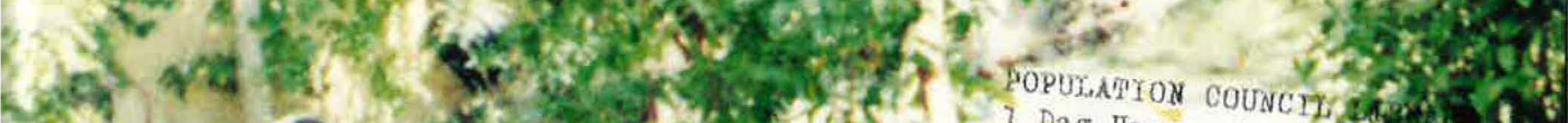

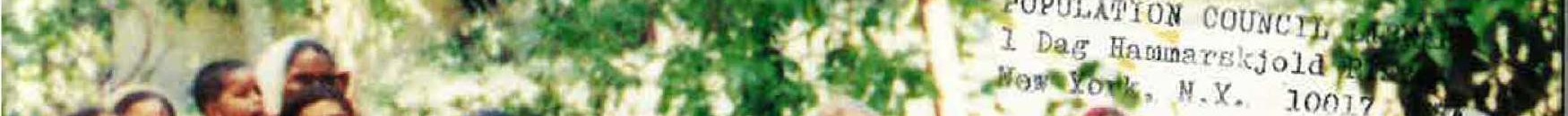

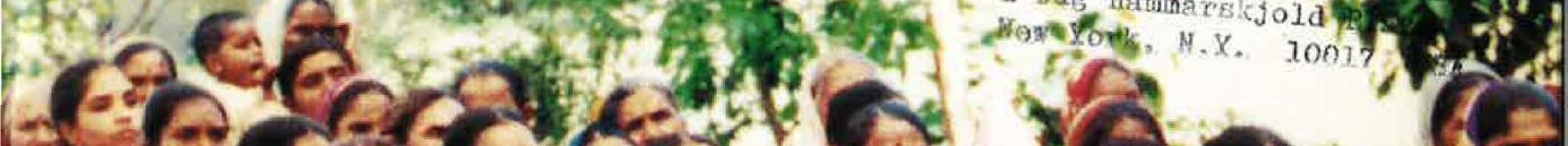

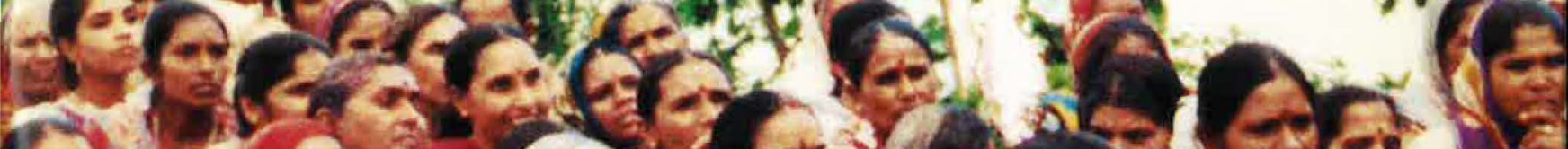

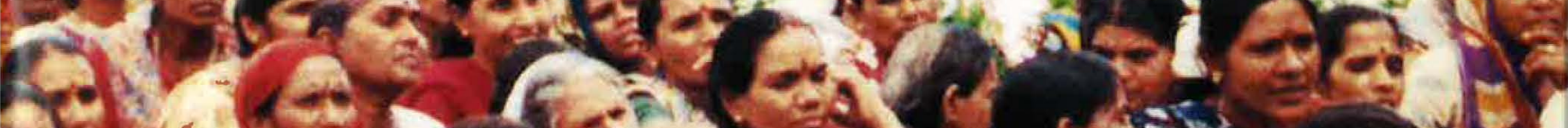

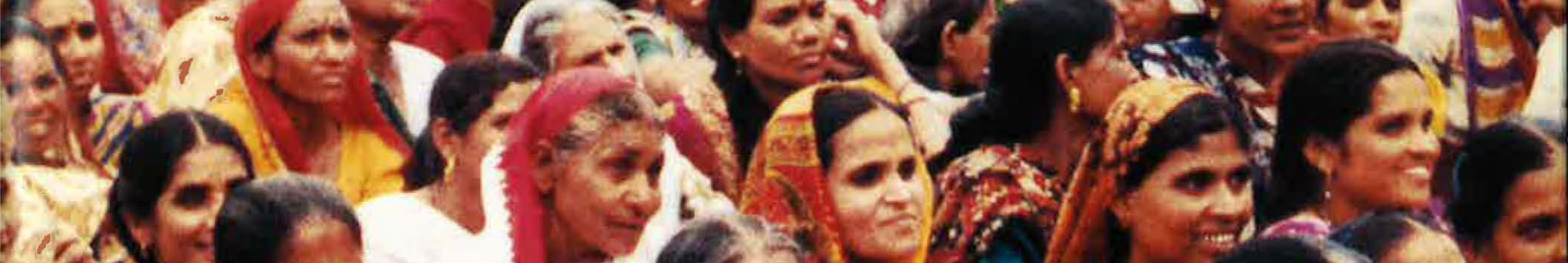
$\operatorname{lig} x=2$ And 2 
SEEDS is a pamphlet series developed to meet requests from all over the world for information about innovative and practical program ideas developed to address the economic roles and needs of low income women. The pamphlets are designed as a means to share information and spark new initiatives based on the positive experiences of projects that are working to help women generate livelihoods and to improve their economic status. The projects described in this and other issues of SEEDS have been selected because they have served not only to strengthen women's productive roles, but also to integrate women into various sectors of development both social and economic. All projects documented in the SEEDS series involve women in decision-making, organize women locally, and address broader policy issues which affect the economic roles of women.

These reports are not meant to be prescriptive, since every development effort will face somewhat different problems and possibilities. Rather, they have been written to describe the history of an idea and its implementation in the hope that the lessons learned can be useful in a variety of settings. They are also being written to bring to the attention of those in decision-making positions the vital roles that women play not only in the economies of their individual households but also in the economic life of every nation.
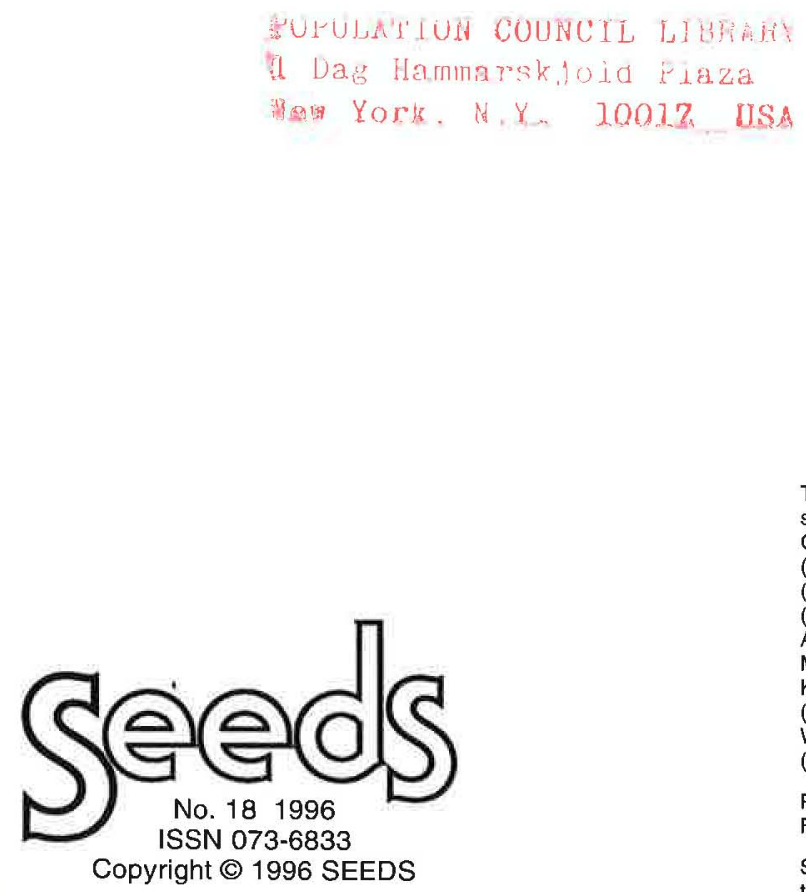

The Population Council provides project direction and administrative support for SEEDS. Editorial policy is set by the SEEDS Steering Committee: Judith Bruce (The Population Council), Betsy Campbell (The Ford Foundation), Marilyn Carr (UNIFEM), Marty Chen (Harvard Institute for International Development), Margaret Clark (The Aspen Institute), Misrak Elias (UNICEF), Anne Kubisch (The Aspen Institute), Ann Leonard (The Population Council), Elizabeth McGrory (The Population Council), Cecilia Lotse (UNICEF), Katharine McKee (Center for Community Self-Help), Kirsten Moore (The Population Council), Aruna Rao, Jennefer Sebstad, Anne Walker (International Women's Tribune Center), and Mildred Warner (Cornell University).

Publication of SEEDS is made possible by support of the Ford Foundation and the Population Council.

Statements made and views expressed in this publication are solely the responsibility of the authors and not of any organization providing support for SEEDS. 


\title{
Out of the Shadows: Homebased Workers Organize for International Recognition
}

\author{
By Renana Jhabvala and Jane Tate*
}

\section{Introduction}

This issue of SEEDS is one of several forthcoming editions that will focus on promoting the economic empowerment of women workers in selected occupations that employ large numbers of low-income women around the world (e.g., homebased work, street vending, waste recycling). Each will begin with a global overview of the situation of women workers in the selected occupation or trade and an analysis of the common obstacles they face. This will be followed by a description of the common strategies that have been developed by programs operating in a variety of settings to help these women overcome the constraints, both traditional and modern, inherent in these occupations. This issue focuses on the situation of homebased workers worldwide.

\footnotetext{
* The authors would like to acknowledge the contributions of Martha Alter Chen and Jennefer Sebstad in preparation of the global overview of homework for this edition of SEEDS. Material for the introductory and SEWA sections has also been drawn from the book Where Women Are Leaders: The SEWA Movement in India by Kalima Rose, 1992 (London: Zed Books).
} 


\section{A Note on the Terminology}

The term "homebased worker" has been used by organizations in Asia to cover a range of people, mainly women, who work at home regardless of their exact conditions of employment. In industrialized countries, the term "homeworkers" has generally been used in reference to "piece-rate" workers who complete specific steps in the production process for an employer or subcontractor in their homes. "Homeworker" is also the term currently in use by the International Labour Organization (ILO) and is generally understood to mean those working at home who are dependent on employers or intermediaries for work. However, it is not uncommon to see the terms used interchangeably among those working in the field in different parts of the world.

\section{What is Homebased Work?}

Homebased work is often seen as an oldfashioned and declining form of production, associated with the early stages of the industrial revolution, not modern economies. Indeed, homebased work spans continents and centuries. Some of the oldest forms of work, such as weaving and spinning, were done at home; today some of the newest forms of work connected with computer technology and modern telecommunications are increasingly taking place outside of a central work site.

Therefore, rather than receding, homebased work is in fact a vital and growing part of economic modernization, its growth exponentially linked to the globalization of industry and the never-ending search for less costly sources of labor and more efficient means of production. As governments seek to attract industrial development, the availability of lowcost labor and labor stability is a valuable bargaining commodity. In today's international marketplace, it is not uncommon for a single garment or electronic device to be a compilation of the efforts of workers on two or three continents, most of whom are not even aware of each others existence.

On the other hand, within the garment trade, quick changes in fashion and demands from retailers for an immediate response have led to the need to produce high fashion garments rapidly and customized to a specific marketplace. Such uncertainties in demand has resulted in a highly competitive local manufacturing industry which has to rely on subcontracting orders out to small producers rather than entailing the risk of production in large scale factories halfway around the world. It is well-known that the Japanese model of "just in time" production (organized at the last minute) was based on the existence of thousands of small subcontractors who were able to draw upon the skills of women working at home.

So, while homebased work in both developing and developed countries (including Europe and North America) may be considered "informal" by most economists-in the sense that workers are outside the protection of the law and their work is often not valued appropriately - most of the products they produce are sold by large, mainstream retailers. The same pattern that is true for clothing can also be found in the automobile industry, all types of electronics production and assembly, and many other modern industries.

In more advanced developing countries other forces can be seen at work. In Thailand, for example, as wages in the cities have risen, Thai products have become expensive as compared to their competitors in other less developed Asian countries. Local industries therefore are relocating to rural areas where small workshops can be set up less expensively. There they can take advantage of worldwide trends in agricultural production that are making subsistence farming less viable. New farming techniques also require cash to purchase inputs such as fertilizer and pesticides, while the growing influence of the mass media brings with it an increased demand for consumer goods. The result is the need for rural families to develop other ways of earning income.

In sum, homebased work in all of its diverse forms cannot be viewed as an artifact of traditional economies. Rather such work appears to be growing in both modernizing rural and urban economies. Further, the income it produces is not supplementary but rather increasingly vital to families and nations alike. The women who embroider on the island of Madeira, Portugal, the homebased workers assembling electronic devices in Brazil, the Chinese women machine stitching garments at home in major cities in Canada or Australia are all inextricably linked within the worldwide marketplace. 


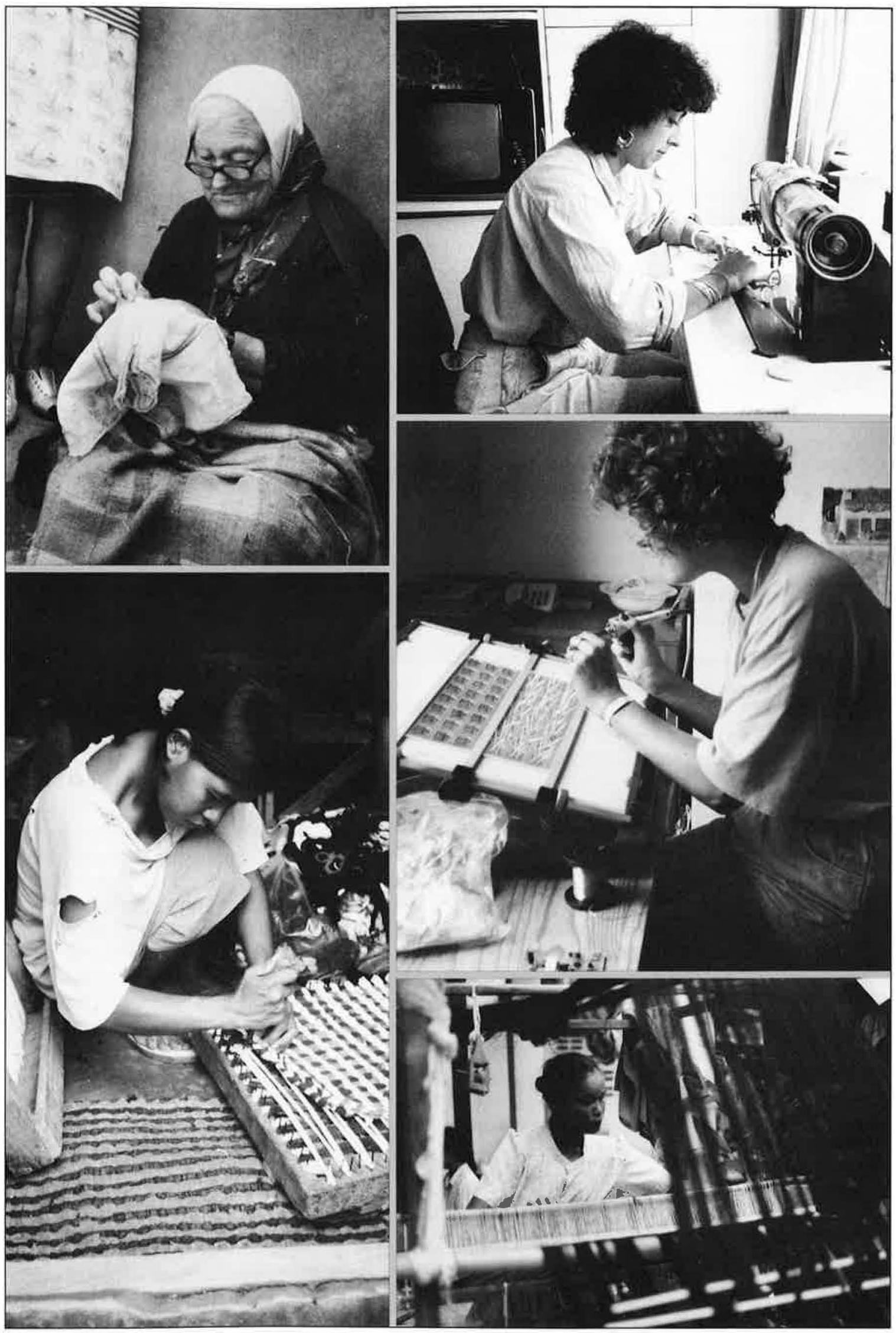


Rabiya Bibi sews garments at her home, in a slum area of Indore, a city in central India. She is a widow with three daughters and two sons; the oldest is fifteen years old. Six years ago, while her husband was still alive and employed, she bought a second-hand sewing machine and began to stitch petticoats together at a rate of six rupees (approximately U.S. \$.35) per dozen.

However, when Rabiya Bibi's husband died of tuberculosis and all their savings went to pay his hospital expenses, Rabiya had to sew day and night to make ends meet. Her children had to leave school to work-her daughters helping with the sewing as well as housework and minding the younger children. Rabiya rented a second sewing machine in order to increase her earnings, but even with her two daughters also working 12 to 14 hours a day, the family still lives below the officially defined urban poverty line.

\section{The Predominance of Women in Homebased Work ${ }^{1}$}

Rabiya Bibi belongs to a vast and often invisible labor force - homebased workersabout which we really know much too little, including how many there actually are. According to the ILO, ${ }^{2}$ homework is women's work almost by definition, so it is not surprising that it is often wrongly confused with housework or domestic work. The invisibility of homebased workers is directly related to the traditional isolation of women within many societies that restricts their interactions with other women outside of their families or immediate communities. It is not surprising that many of these women, when surveyed, refer to themselves as "not employed," or as "housewives", even when they are spending 14-16 hours a day earning income to support their families. They carry out their tasks with minimal contact with the outside world, often having little understanding of where the work comes from or where it goes once it leaves their hands.

The over-representation of women in homebased work is common in developed and developing countries alike. In the Federal Republic of Germany, Greece, Ireland, Italy, and the Netherlands, 95 percent of known homeworkers are women; in France, 84 percent; in Spain, 75 percent; and in the United Kingdom,
95 percent. ${ }^{3}$ While data from the developing countries are less systematic, studies in Brazil found that homebased piece-rate workers were mainly women; in India, nearly 90 percent of the five million bidi workers (rollers of indigenous cigarettes) were women. Large numbers of immigrants and ethnic minorities also turn to homebased work as they not only face discrimination in the labor market but must also contend with barriers to formal employment such as problems of language, culture or legal status. Disabled individuals in many countries also face restricted employment opportunities and thus have little alternative but homebased work.

When the Self-Employed Women's Association (SEWA) in Ahmedabad, India first began surveying women homebased workers, across every trade women told them that what they needed was more work. Yet these same women were already laboring as much as 16 hours per day, often having to carry their children with them while they worked. Because they could not perceive themselves as having the ability to negotiate better working conditions, the only solution they could see to their poverty was to get more work. This world view plays right into the hands of the contractors and middlemen who exploit their vulnerability to the benefit of themselves and the industries that employ them.

Therefore, it is not surprising that one of the first steps in bringing such women out of the shadows is to help them internalize the concept that they are in fact "workers" to the same, or sometimes to a greater extent, than their fathers, husbands and sons.

\section{How Prevalent is Homebased Work?}

It is difficult to determine the extent of homebased work internationally as few countries collect national level statistics on this elusive, yet pervasive form of employment. A 1990 review of 70 countries for which the ILO has data found that only seven countries (Federal Republic of Germany, Hong Kong, Italy, Japan, Morocco, Liechtenstein, and Switzerland) actually collect data on homeworkers. One difficulty is the lack of international statistical guidelines that define homework, which not only hinders the collection of such data but makes in- 


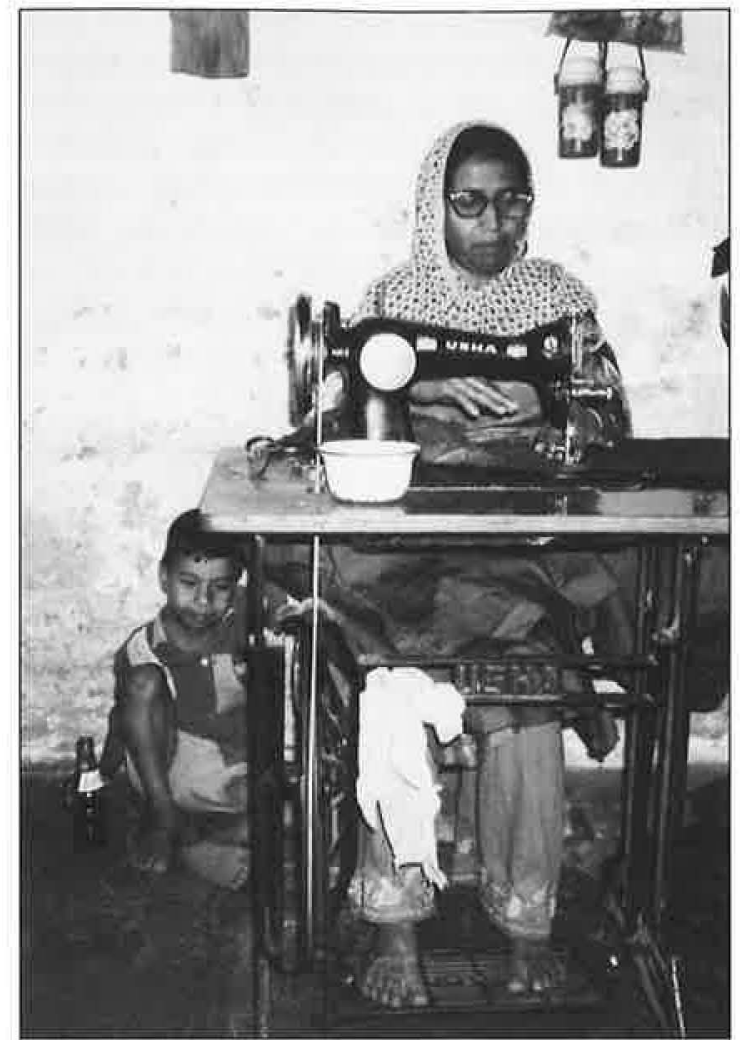

ternational comparisons of existing data difficult. Moreover, whatever official statistics exist probably underestimate the number of homebased workers because such activities are often invisible or clandestine.

\section{What Are the Different Types of Homebased Work?}

Though many of the issues homebased workers face are similar, it is still important to describe the full range of homebased work and the varying degrees of difficulty that homebased workers confront in making a decent living. Basically, there are two principal types. Homebased workers such as Rabiya (profiled above) are piece-rate workers. They get their raw materials from a trader, a contractor, an employer or a firm, make them into finished goods at home, and deliver their finished goods to the same person. Rarely do these workers have any direct contact with the marketplace for the goods they produce. However, often the raw materials they receive from the factories or contractors are not sufficient, or certain necessary components are not provided to them, so they have to buy these items themselves. Rabiya, for example, buys the thread she needs for sewing from the market. Recently the price of thread went up, so she now spends almost 20 percent of her earnings just on thread. And while some employers or contractors loan equipment to their piece rate workers, most have to provide their own tools. Thus the cost of equipment, maintenance and infrastructure, such as electricity, can also cut deeply into the workers' earnings.

The employers spend nothing. They should actually be paying homebased workers more than factory workers, since we bear these expenses.

Rahima Shaikh, organizer of garment stitchers, Ahmedabad, India ${ }^{4}$

Another type of homebased worker is the own account worker. She is generally in direct contact with the market, buying her own raw material and selling her own finished goods. However, in terms of earnings and working conditions, she is rarely much better off than her piece-rated sisters. Own account workers face competition from larger more powerful businesses and rarely have access to credit, except at exorbitant rates of interest. Thus, they have to buy raw materials in small quantities, making them more expensive, and rarely are they able to sell their goods themselves directly in the markets. Thus they too are generally reliant on agents, contractors and other middlemen.

So although there is a theoretical difference between a piece-rated worker, who is "dependent" on a specific employer or a contractor, and an own account worker who is supposedly "independent," in practice this distinction tends to blur. For example, bidi workers in India are generally considered to be piecerated, but some employers now require these workers to "buy" from the company the tobacco and leaf they roll and then "sell" the finished bidis back to the company in order to make it appear that these workers are "independent." Similarly, weavers in Thailand are own account workers in that they buy their own yarn and sell their cloth in the market. However, to do this they generally must buy their material on credit from the same merchants to whom they eventually sell their finished goods - and at prices determined by the same merchants. So, although technically the pro- 
ducer is an own account worker, she has no direct access to the best markets and limited bargaining power.

\section{Key Industries and Sectors for Homebased Work}

Homebased work is a principal production strategy for many manufacturing industries that involve labor-intensive manual or machine tasks (such as sorting, cleaning, packaging, labeling, coil winding, soldering). Small-scale studies from around the world show that within the manufacturing sector, homebased workers continue to play a vital role in the clothing and textile industries, the leather industry, artificial flower making, bidi (cigarette) rolling, and carpet making. In recent years, as manufacturing has restructured and decentralized, there has been increasing use of homebased workers in the production of electronic equipment and in the service sector (activities such as filling envelopes, mailings, typing, word and data processing, invoicing, editing, and translating.)

\section{How Widespread is Homebased Work?}

A number of small studies have been carried out on homebased workers. Only a few even estimate the proportion of home-based workers in a particular sector. Nonetheless, their findings give an indication of the proportion of homebased workers concentrated in particular trades and services across regions and countries. For example, homebased workers account for 45 percent of all clothing industry workers in Venezuela ${ }^{5}$ while, in Buenos Aires, Argentina, homebased workers make up 31 percent of all clothing workers, 12 percent of wood and furniture makers, and 21 percent of workers in non-specific manufacturing. In Mexico, an estimated 30 percent of the labor force in the garment industry are homebased workers. ${ }^{6}$

In 1986, homebased workers made up an estimated 38 percent of workers in Thailand's wearing apparel industry and 25-39 percent in the Philippines. ${ }^{7}$ On the island of Madeira, Portugal, they constitute over 95 percent of the total embroidery industry workforce and represent nearly 20 percent of the island's ecomically active population. ${ }^{8}$

\section{Location of Homebased Work}

Homebased workers are found in all types of economies, modern and traditional. While they are often concentrated in industrial areas and large urban centers - such as London or Paris, Ahmedabad or Mexico City-

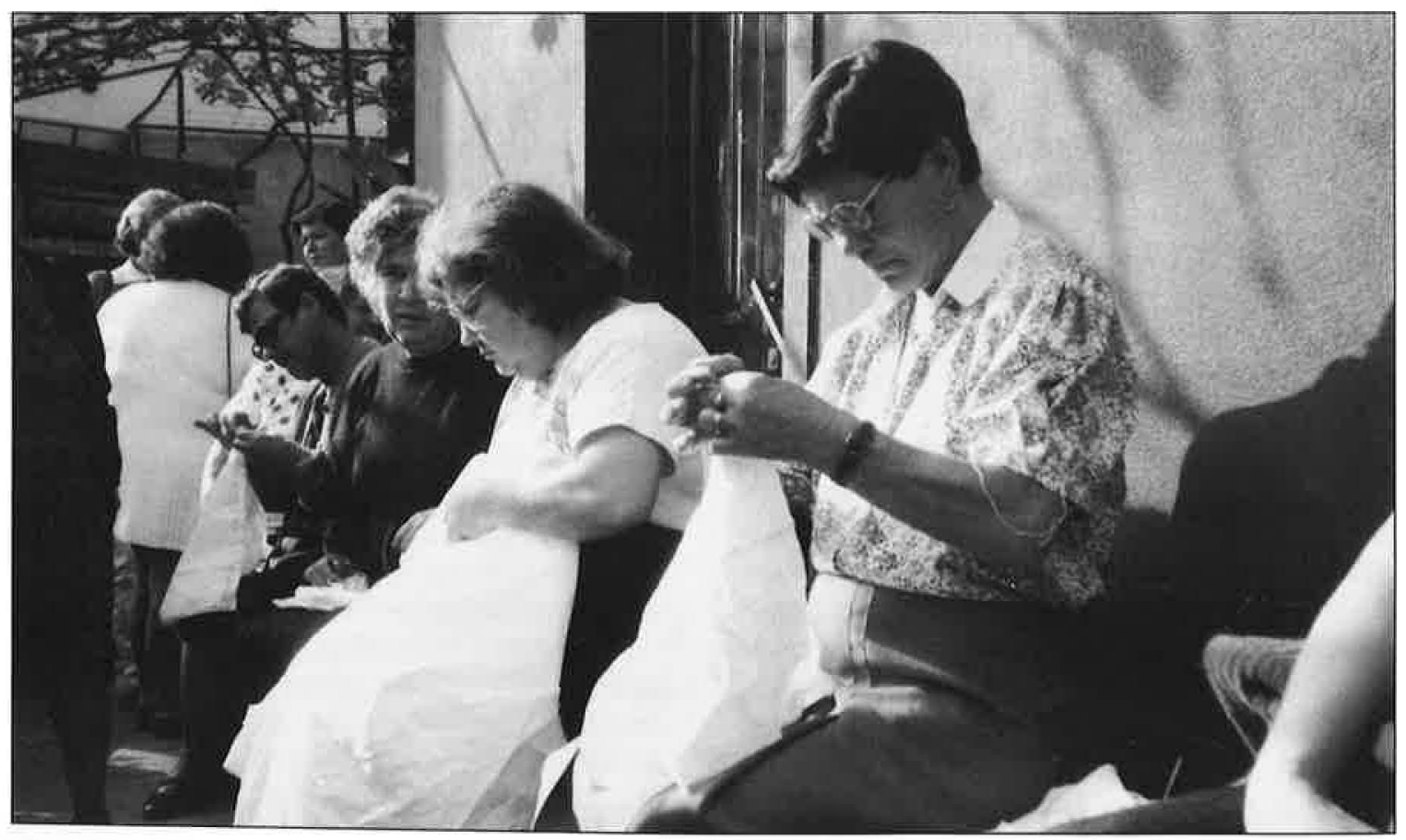


many recent studies have shown that modern forms of homebased work provide a growing source of employment in rural areas as well; this is true in Spain and Greece, in Southeast Asia and India, and in the USA.

\section{CONDITIONS OF HOMEBASED WORK}

\section{Homebased Workers Are Generally Poorly Paid}

It is almost universally true that in all economies the earnings of homebased workers are lower than other workers, and often less than the minimum wage. In a study done by the Self Employed Workers Association Academy in India, it was found that 85 percent of the workers sampled in 14 trades were earning 50 percent below the official poverty rate ${ }^{9}$ Similarly, a report from the Self Employed Women's Union (SEWU) in South Africa found that 65 percent of women homebased workers were earning less than the minimum wage each week. In Australia, the Textile Clothing and Footwear Union found that "out workers," (as they are known locally) who typically work 12 to 18 hours per day, seven days a week, earn about a third of the standard rate of pay. ${ }^{10}$

\section{Homebased Workers Often Are Not Recognized by Governments and Are Rarely Covered by Even Minimum Worker Benefits}

Unlike other types of workers, homebased workers rarely have any access to social security benefits of any kind, such as health care, child care or old age pensions. While it is true that developing countries rarely have social security systems, most formal sector workers are protected by specific laws, while homebased workers are not. Or, even if covered in theory, most have no knowledge of, or ability to gain access to, these services. For example, the state of Gujarat in India has a series of laws that regulate and protect bidi workers, and provides health centers specifically set up to serve these workers and their families. However, these rights were estab- lished through union organizing when bidi rolling work was done within factories. To avoid complying with this legislation, which increased their costs, cigarette companies began to give out the work of rolling bidis to homebased workers-who are predominantly women. Until they were organized by SEWA (see next section) these women had no idea that these laws even existed. And while they were aware of the health center, they could not use its services because they did not have cards identifying themselves as bidi workers.

Even in developed countries, homebased workers tend to be excluded from benefits and protection because their earnings disqualify them for welfare benefits, or they are officially classified as self-employed, or they are restricted from seeking assistance because of language, education or legal barriers.

\section{Homebased Workers May Appear to be Independent but in Most Cases They Are Not}

On the surface, homebased workers may seem to have substantial latitude in terms of the hours they work, the materials they use, and when and how they want to work. But in reality, their supply and marketing relationships are most often simply a disguised and unregulated form of employer-employee relationship, camouflaged through an often complex arrangement of agents, traders and subcontractors.

\section{Homebased Workers Have Special Housing Requirements}

As the name implies, homebased workers work at home. But because the majority are poor, in both developed and developing countries, work and family life must co-exist in very cramped quarters.

Once we got into their neighbourhoods, we could always locate the workers-their houses are so small they have to pull their machines out onto the footpath.

SEWA Organizer, Ahmedabad, India ${ }^{11}$ 


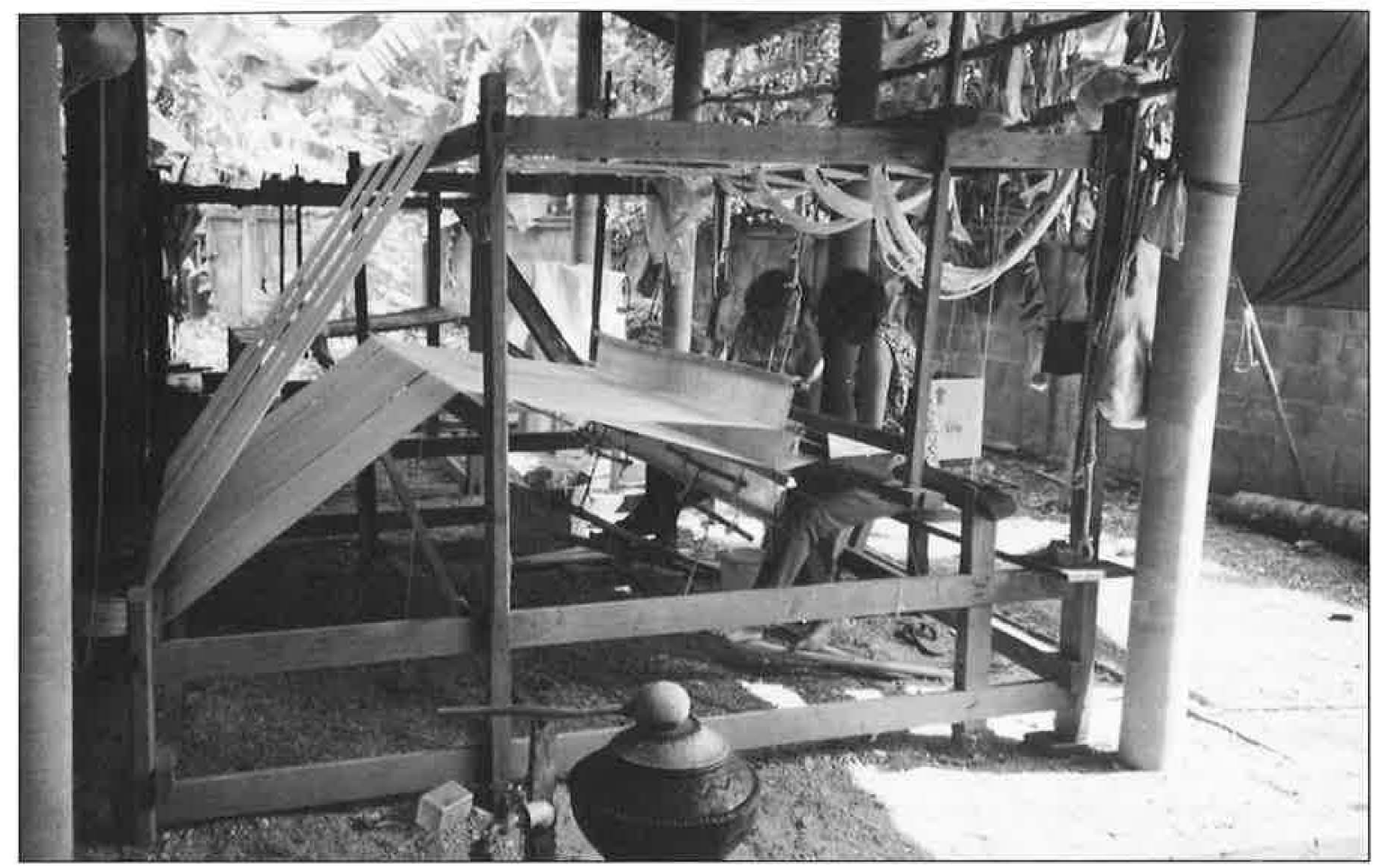

In addition to lack of space, many of these homes lack adequate light or other facilities. In addition, in many situations they are vulnerable to fire, theft and both natural and civil disturbances. As many of the workers also have no title to their homes, they may find themselves literally "out on the street" at the whim of husbands, in-laws, landlords or local governments.

After losing her job at a health center, Beauty and 12 other women living in the Umlazi township outside of Durban, South Africa started a sewing project to earn income. Beauty is a single mother and the sole supporter of her two children. However, this was the period leading up to the first democratic elections in South Africa and violence was rife. Beauty's house was attacked and dismantled and she was robbed of all her furniture. The sewing group disintegrated as the women sought safer places to stay. It was only after she joined the Self Employed Women's Union that Beauty was able to get the assistance she needed to get back in business. Today she is again working at home, in a shack she has built for herself in another township, sewing on a hand-operated machine as there is no electricity.

\section{EFFORTS TO IMPROVE THE LIVES AND WORKING CONDITIONS OF HOMEBASED WORKERS AROUND THE WORLD}

The persistence and indeed the growth of homebased employment worldwide and the uncertainty and discrimination these women face in their work conditions and marketing arrangements have led workers in different parts of the world to join together to improve their situation. The following are examples of some of these efforts from different parts of the world, from both developing and developed countries. While their approaches may vary, each effort is directed towards improving the selfesteem, work relations, and remuneration of these workers as well as helping to gain official recognition for and policies in support of this vital, largely female workforce.

\section{India: Self Employed Women's Association (SEWA)}

India has a large and growing homebased work force in both urban and rural areas. Although there is no official count, in 1991 the Commission on Rural Labour estimated 
that there were about 20 million homebased workers in rural areas alone. The Self Employed Women's Association was the first organization to draw national attention to these workers and, in fact, the term "homebased worker" was coined by SEWA.

SEWA is a trade union formed in 1972. However, it is not a union in the traditional sense. Rather it is a movement that represents the confluence of three different movements: the labor movement, the cooperative movement and the women's movement. SEWA is located in the state of Gujarat, birthplace of Mahatma Gandhi, and Gandhian principles are the inspiration behind SEWA. SEWA organizes women to enter the economic mainstream through the twin strategies of struggle and development. The union struggles on behalf of its members at three levels: the exploitation they face directly from employers; their lack of influence before the law and with government bureaucracies; and their exclusion from the process of developing relevant policies and legislation.

SEWA members include three main categories of self-employed women:

- Hawkers and vendors who sell their wares (vegetables, fish, fruit, eggs, prepared foods, household goods, ready-made and used clothes, etc.) from carts, baskets or in market stalls.

- Manual laborers and service providers, such as agricultural laborers, construction workers, contract laborers, head loaders (women who transport commodities on their heads, such as construction materials), cart pullers, laundry and domestic workers.

- Homebased workers such as weavers, potters, bidi(cigarettes), agarbatti(incense) and papad (bread) rollers, garment makers, processors of various types of agricultural produce and crafts women.

In India today more than 93 percent of wage earners are self-employed workers laboring in these types of trades. And women constitute more than half of the self-employed! In 1994 SEWA's membership was nearly 220,000 , and 40 percent of members were homebased workers.
As a union, SEWA has organized homebased workers to demand higher rates and better working conditions. For example, whereas most homebased work is not regulated by law, bidi workers (as noted above) are covered by the Bidi and Cigar Workers (Conditions of Employment) Act, and their rates are fixed by the government. When SEWA first began organizing homebased bidi workers in 1979, they were earning Rs. 8 per thousand cigarettes rolled, which was about half the minimum wage. After a struggle of nearly ten years-during which SEWA workers held rallies, sit-in protests, a strike, and filed four cases in various courts - an agreement was finally reached with employers. Today bidi workers in Ahmedabad are earning Rs. 25 per thousand, which is equal to the minimum wage.

Garment workers, on the other hand, were not protected by any laws, including the Minimum Wages Act. In this case, the union's struggle took the form of trying to get them protection under the law. It took five years, but a law was finally passed. Today garment workers too are covered by minimum wage laws. SEWA has carried out similar struggles on behalf of incense stick workers, cotton pod shellers and embroiderers.

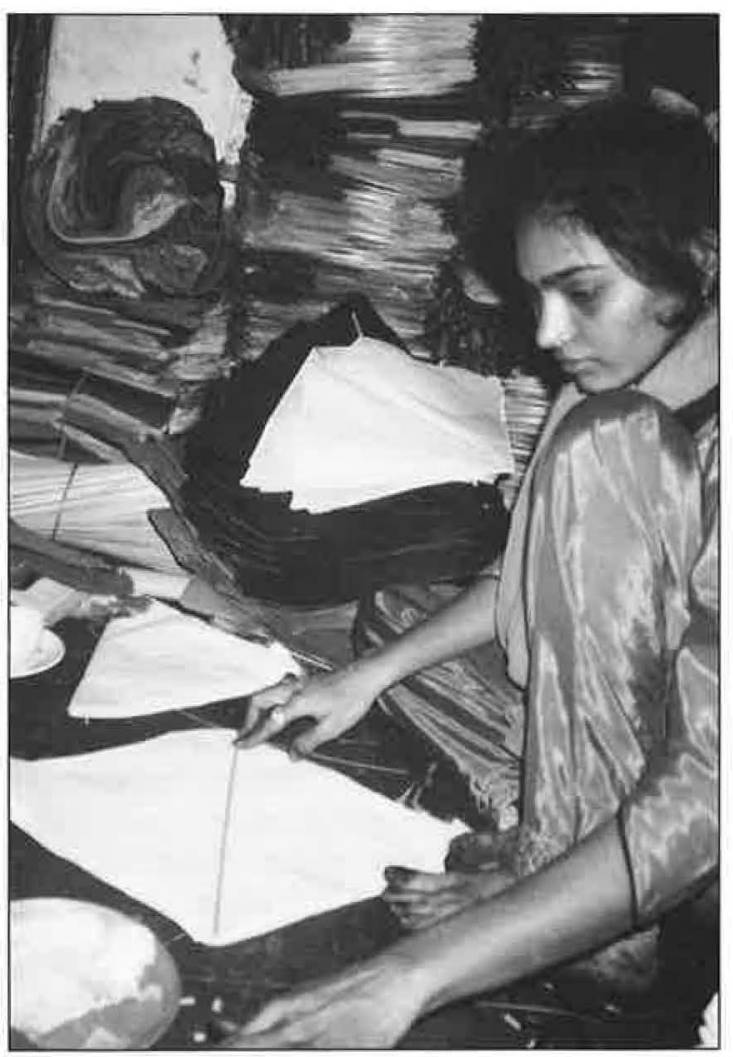


However, SEWA soon found that getting such laws passed is not enough. For them to be implemented means a long and arduous process requiring hard and often bitter struggles. And because homebased workers are economically and socially vulnerable and have little or no bargaining power, it is very difficult for them to sustain such long term struggles. For this reason, SEWA's emphasis has shifted to the adoption of alternative economic systems like cooperatives. By working together in cooperatives, women learn how to access markets themselves, bypassing the middlemen and moneylenders, and are better able to access social benefits such as healthcare, childcare, savings programs, and insurance.

Within SEWA, chindi workers were the first to organize themselves into cooperatives in order to buy cloth and market their goods collectively. Chindi is fabric sewn from waste cloth left over from the production of textiles in large mills. Traditionally, women received this cloth from traders and sewed it into pillow covers, quilts and blankets. They were paid piece rates for this work. When some of the women began to organize to demand higher piece rates, the traders refused to give them any work at all. It was then that SEWA organized the women into a cooperative so that they could buy leftover cloth directly from the factories themselves. The traders had tried to convince the women that if they paid higher piece rates they would be forced out of business. The cooperative, however, paid higher rates from the start and still made a profit; clearly demonstrating that fair wages and profitability are not mutually exclusive. And as a result of the piece rates paid by the cooperative, private traders are now offering the same rates to their workers (and they haven't gone bankrupt yet).

In urban areas the chindi workers were followed by hand block printers, bamboo workers and bidi rollers; in the rural areas by embroiderers, leather workers and weavers. Ultimately these cooperatives have joined together to form federations and many have acquired their own marketing outlets. For women such as these, coming together in a cooperative marks the first time in their lives that they have ever actually owned something of their own and had decisionmaking power over it. This change in consciousness from a piecerate worker to a worker-owner is a monumen- tal one in terms of women's personal and economic empowerment. Further, the government provides different forms of financial and policy support to officially registered cooperatives in India, thus giving poor women access to a range of existing benefits and services that they could never benefit from on their own.

Building a cooperative, however, is not easy. The first difficulty is that before they can compete effectively in the marketplace many of the women need to upgrade their skills. In other cases workers lack certain crucial skills required to carry out the complete production process themselves because traders have kept this information from them. Block printers, for example, found that though they could do the printing they did not know the art of color mixing. Embroiderers found out that the color combinations that they were using were not suitable to the tastes of metropolitan consumers, so they had to learn to develop new combinations.

Marketing-i.e., understanding who the buyers are, what quality work they need, where and when they need it, and establishing links with these markets-is another hurdle that these cooperatives have to face. Perhaps some of the proudest moments for homebased workers has been when they have been able to open their own shop in the same location as their former employers.

SEWA has also been able to organize women around issues of health.

This body is my only asset. On days I work, I earn. When I am sick, I cannot earn. My fire stays cold those days. There is no other body, no other asset to fall back on...

Kantibehn, an agricultural laborer, India'12

In fact, when venturing into new territory, SEWA has found that organizing around health is one of the most effective and nonthreatening ways to bring women together. In particular, early research by the Association documented that childbirth was one of the greatest risks faced by self-employed women. This resulted in SEWA establishing its own package of maternity benefits in 1978; in 1987, it was successful in getting the state Labour Ministry to provide this coverage to landless agricultural workers through its Maternity Protection Scheme. SEWA has also trained 44 women 


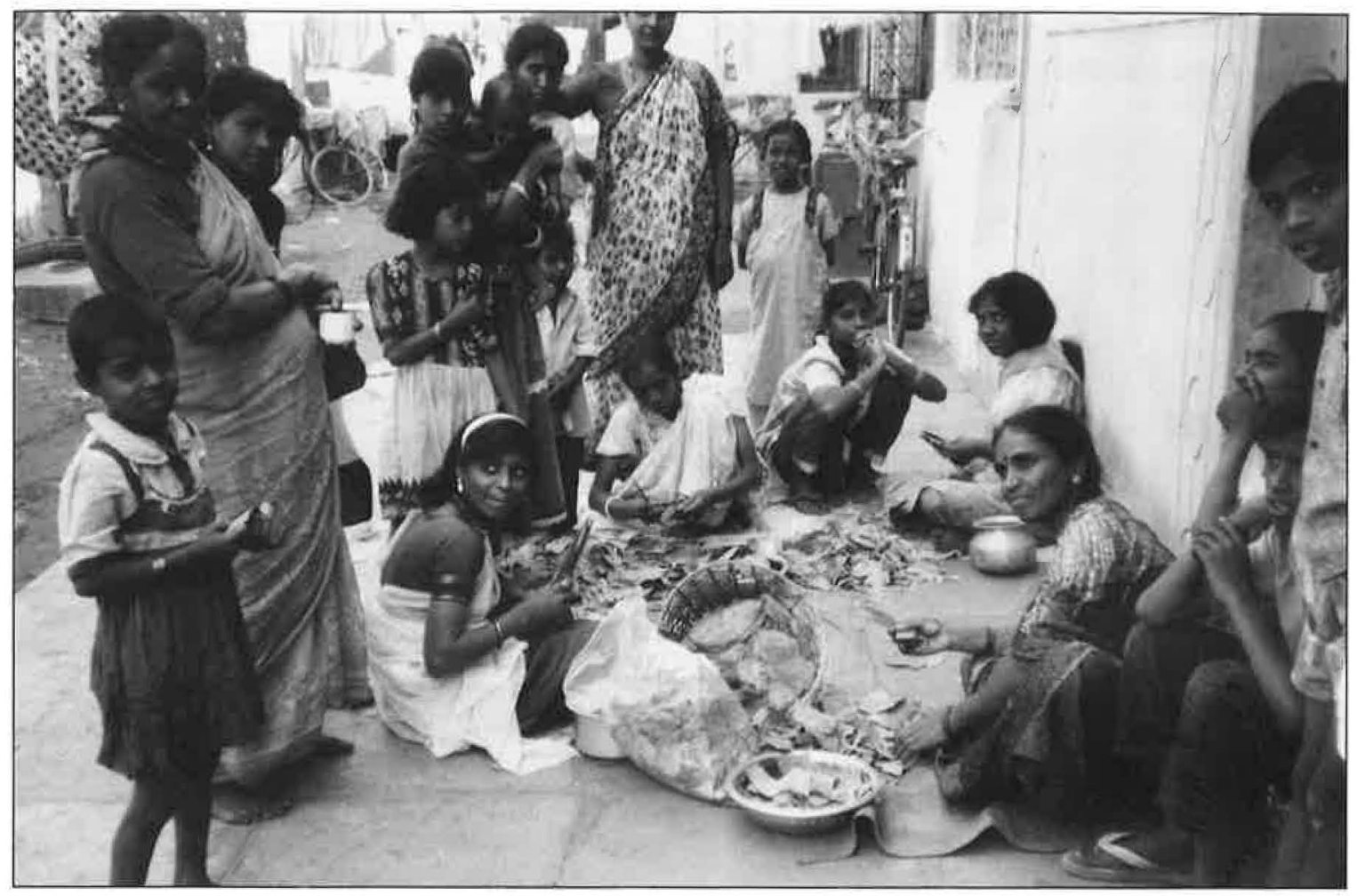

who serve as community health workers and has developed health worker and child care cooperatives-successfully lobbying for the inclusion of the latter under the government's Integrated Childhood Development Scheme. These cooperatives provide services to other SEWA members at reasonable rates.

Gaining access to social security is another area where SEWA seeks to help homebased workers. In collaboration with national insurance companies, SEWA has been able to help insure 12,000 of its members against the natural, social and individual crises that continually threaten their lives and work. Coverage includes death, sickness, widowhood, and loss of household goods and work tools in case of flood, fire, riot, or storm.

Another major need of homebased workers is access to credit. At SEWA, this is met through the SEWA Cooperative Bank, founded in 1974. SEWA Bank is without doubt a women's space. The women say, "it is like my mother's place," somewhere they feel comfortable and at home. They also refer to the bank as "the village well," a place to come together and talk with other women about their work.

Most of the loans made by the SEWA Bank are unsecured because initially poor women have little besides their jewelry that can be offered as security. But the women in the union and in the cooperatives are all encouraged to own their own tools, maintain a savings account in their own name and, if possible, to have their land or home registered in their own name (or at least jointly with their husbands).

Forty percent of SEWA bank loans are for housing or related productive expenses. Since a homebased worker's house is also her workplace, women take loans to buy land and building materials; they add on to existing houses by building a porch or putting down a cement floor, and they install connections that will provide access to running water and electricity. Today the bank has nearly 50,000 depositors and capital assets of Rs. 1.2 million.

Beyond Gujarat, SEWA has been actively advocating for homebased workers at the national level by holding seminars and workshops for policy makers. In 1989, Ela Bhatt, SEWA's General Secretary, was appointed to head a National Commission on Self-Employed Women established by the Prime Minister. Now, along with a group of lawyers, SEWA has helped to draft a Homebased Workers Protection and Welfare Act which has been introduced into the national Parliament and is now leading a national campaign to ensure its passage into national law. 


\section{United Kingdom: The West Yorkshire Homeworking Unit}

Rabiya Bibi's English counterpart, Julie, lives in West Yorkshire. She is 29, married and has two daughters. Her husband has a lowpaying job as a laborer. Julie used to work in an office but when her second child was born she decided to stay at home because childcare was both difficult to arrange and expensive. However, as the family still needed two incomes, she decided to look for work she could do at home.

Julie had always liked knitting and embroidery, so when she saw a card in a local shop saying "Hand-Knitters Wanted," she answered the advertisement. A woman came to her house and gave her patterns and wool. This agent regularly gives out work to 20 to 30 women in the area. The sweaters and jackets they knit are then sold by a large mail order company.

Soon Julie was working as long as 30 hours per week and being paid 5 pounds per garment [apx. US \$7.60]. Imagine how she felt when she found a catalogue where the sweaters she had knitted were being advertised for ten times that price!

At first, she did not count the hours she spent knitting as she enjoyed the work and her family needed the money. But one day the agent told her that her garments were the wrong size and refused to pay her. Julie was sure this was just a ruse, as her work had always been right before, but there was little she could do about it: she had no written contract and there was no one she could complain to. So, she gave up knitting and looked for other work.

A friend then told her about electronics work that could be done at home. So she went down to the factory where a supervisor showed her how to assemble tiny electronic parts and solder printed circuit boards. The good news is that this work pays better than knitting. When there is enough work, Julie can earn up to 80 pounds (about US \$54) a week for about 50 hours work. But she still gets no holiday pay nor does she receive the bonuses given to those doing the same work at the factory. And now Julie has learned that the company wants to reduce the piece rates they pay to their homeworkers.
Traditionally West Yorkshire was famous for its woolen textile industry but that industry is now in decline. But while far fewer people are employed directly in the factories and mills, the industry remains a source employment through homebased or "outwork" as it is known locally. For example, the final process in the making of woolen cloth, called "burling and mending," is now most commonly done by women working at home, usually through a subcontractor. Today many of the newer, smaller companies producing women's fashions officially employ only three or four workers, while unofficially they are giving out work to twenty or thirty machinists working at home. Homebased work in many other industries is also common in West Yorkshire and throughout the UK, in areas such as electronics and electrical goods, engineering, print and packaging, toy-making, knitting (both hand and machine), clerical (typing, filling and addressing envelopes), and data in-putting or word processing using computers.

The West Yorkshire Homeworking Unit (WYHU) was formed by a group of women drawn from employment rights and community groups who were looking at new ways of organizing women workers. When WYHU was set up in 1988, some research on homework had been done by Bradford University, but there was no organizing going on and very little contact with the homeworkers themselves.

The vast majority of homeworkers in West Yorkshire are women, many with young children. Some are single parents; some live in households where the men are unemployed. Many do homework because they cannot find jobs outside or they need to combine paid employment with child care. The women come from many different areas, both rural and urban, and from different communities. WYHU estimates about half the homeworkers come from minority communities originating in India, Pakistan and Bangladesh.

WYHU began by offering homeworkers confidential advice and support via a free telephone helpline and through community contacts. Wherever possible home visits were made as a follow up to the phone calls. Many of the women reported that it was the first time they had someone they could talk to about their work. They all told a familiar story of low pay, irregular work, no employment rights, health problems, and great insecurity. Yet, despite 
their complaints, they were always afraid of losing their work: no matter how small, their income was vital to their families well-being. Thus the process of establishing trust was crucial and took time.

WYHU employs former homeworkers as outreach workers because they possess a firsthand understanding of the situations these women face and can more easily win their trust. By following up phone calls with home visits they can, over time, establish a relationship of trust. Then, when they are in touch with several homeworkers in one area, they encourage them to get together in neighborhood groups.

The WYHU's first task was to make these women visible. Wherever possible, homeworkers themselves were encouraged to speak to groups of people, in West Yorkshire and beyond, telling their own stories. A newsletter was instituted, intended primarily for homeworkers, but also aimed at educating a wider audience. The newsletter regularly presents an $A-Z$ of home work, listing about one hundred different jobs done at home in West Yorkshire. Articles are written in Urdu, Gujarati, Punjabi, Bengali, and Chinese, as well as English.

WYHU organizes activities to bring homeworkers together, including social events and meetings to deal with problem issues. When a number of women in one particular area are working for the same employer, these meetings provide an opportunity for them to compare rates and talk together about how to tackle common problems they face with their employer. Unfortunately the problem the women most often talk about is lack of enough work and the need to find other ways of earning money.

As their contacts with the homeworkers grew, WYHU began providing legal advice and moral support to individual women, even helping some to take their employers to industrial tribunals to win back pay. Although only half a dozen women were actually successful in court, the newsletter publicized these cases and helped to remove the isolation felt by other women working by themselves at home. At a later stage, a video was made with both English and Urdu soundtracks as many women are verbally bilingual but unable to read either language. Also, due to the popularity of Indian films, most households in this community have video players. The video helped to publicize the existence of the WYHU.

Since 1990, WYHU has been among the many groups who have sought to internationalize the organizing of homeworkers by promoting visits between its constituency and women homeworkers in the Netherlands and Portugal. Recently WHYU has set up a homeworkers' association aimed at develop-

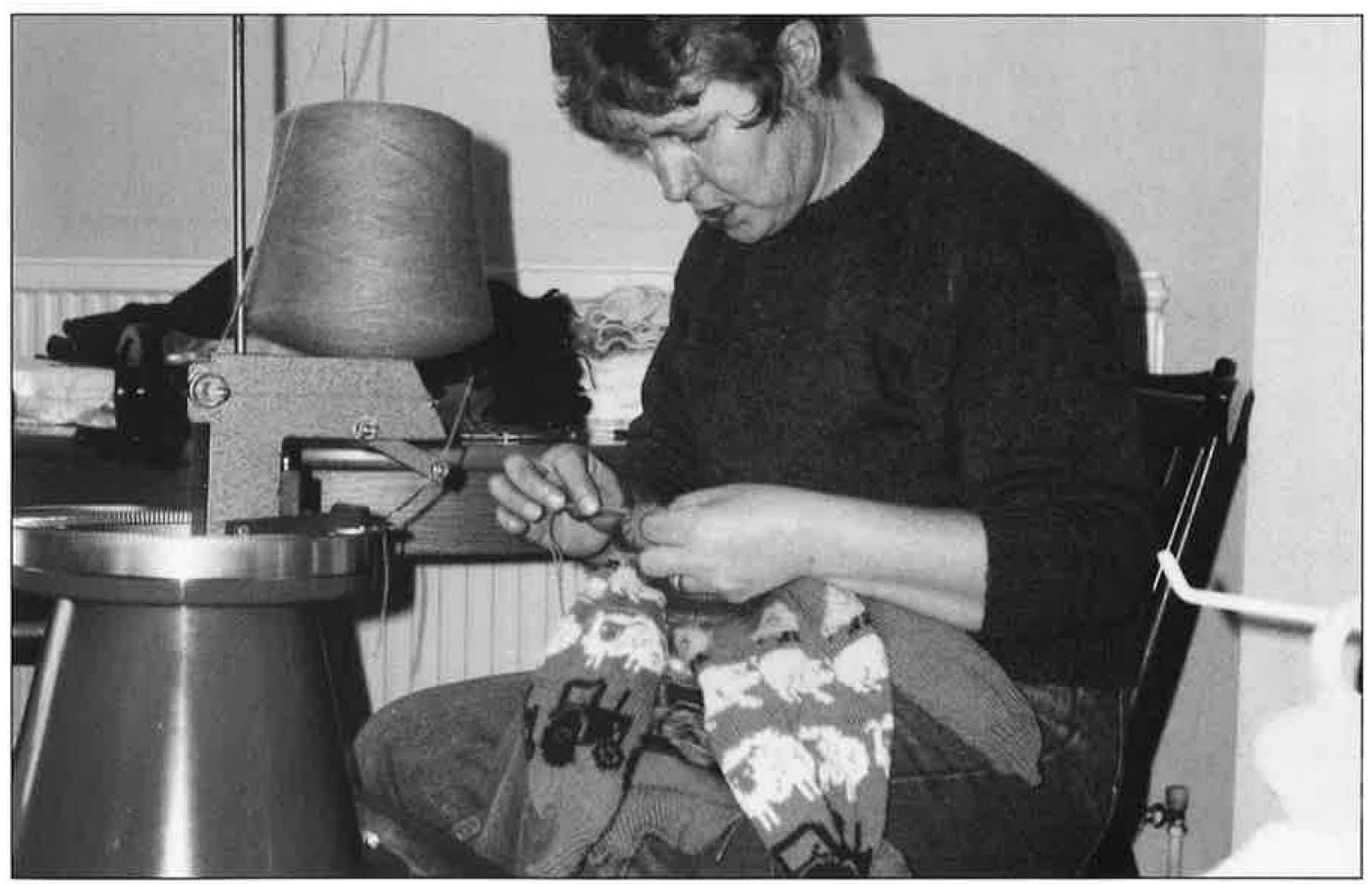


ing an organization that will be able to represent homeworkers' directly instead of being just a community project. The association currently maintains a pilot project in West Yorkshire, but if successful it will expand to other parts of Britain. The impetus for this followed a visit by SEWA organizers to a conference held in Bradford, UK in 1992, where they explained how SEWA operated as a women's trade union.

As WYHU looks ahead, it hopes to make more progress on the national front. A National Group on Homeworking (NGH) was established in 1984 and is the main body campaigning for employment protection on behalf of homeworkers in the UK.

\section{The Philippines: PATAMABA}

Ka Lilay weaves sawali or palm leaves for a subcontractor in her village in the Philippines. She buys palm leaves and bamboo from a local farmer. The bamboo are cut into long strips with sharp knives and Ka Lilay then weaves them into rectangular mats according to specifications provided by the subcontractor. But sometimes the subcontractor refuses to pay her, saying the mats are not of the required quality (but taking them anyway). Then Ka Lilay loses not only her earnings from the weaving, but also her investment in the raw materials. But there is nothing she can do about it-she needs the work.

There are an estimated five to seven million homebased workers in the Philippines doing both piece-rated and own account work in rural and urban areas. Most of this work is done for the export industry and includes stitching garments, embroidery and crocheting. Fabric and designs are provided to the workers by subcontractors who obtain them from the export firms. Here too, piece rates are very low, well below a minimum wage.

The Association of the New Filipina (known as $\mathrm{KaBaPa}$, from its Filipino name), was started in 1975 by a group of rural women to raise awareness of women's need for steady employment and income. In 1988 the ILO asked $\mathrm{KaBaPa}$ to work with them on a project to organize homebased workers. For the women themselves this was the first time they actually began to think of themselves as "homebased workers" rather than just rural women. This new perspec-

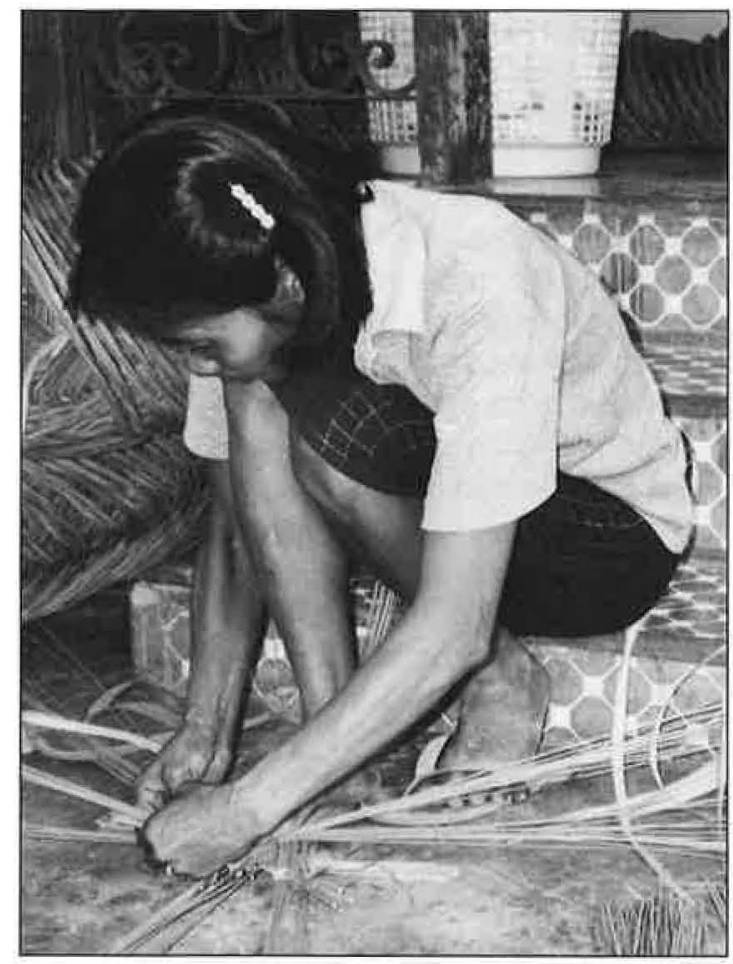

tive helped them to perceive themselves in a new light-as a specific category of workers, with particular needs and demands.

After 29 homebased work leaders from nine provinces held a meeting, it became evident that homebased work was a widespread phenomenon in the Philippines and that they all shared similar situations and similar needs. They also realized that they were in many ways "invisible" to the rest of society, especially policymakers, and that if they wanted to better their lives, they would have to organize nationally. The result was the founding of PATAMABA, the National Network of Homeworkers.

PATAMABA's objective is to strengthen, consolidate and expand the national network of homebased workers and, as SEWA has done, to provide support services for their welfare, social protection, and increased productivity. PATAMABA helps homebased workers form self-sustaining local groups while at the same time working at the policy level to raise awareness about homebased workers and gain support for their cause. Today there are 5,000 PATAMABA members in 28 out of a total of 75 provinces in the Philippines. The majority of members are in rural areas but there are also some urban members.

PATAMBA produces gabays (training materials) in Tagalog and some other Filipino lan- 
guages. They have also helped their members to set up their own microenterprises, or to work cooperatively in groups, in order to become independent of traders and subcontractors. To this end, they provide training in financial management and technical aspects of production, and have set up a three million peso revolving loan fund; their long term aim is to set up their own bank, modeled on the SEWA Bank in India.

PATAMABA has successfully interacted with national trade union federations, with the Department of Labor and with universities and other NGOs. It has also been able to convince the government to support the International Convention on Homebased workers within the ILO (see discussion below). PATAMABA has influenced the government to implement provisions on homebased work within the labor code in order to ensure the rights of homebased workers and provide them with more security and social protection. It is also attempting to work with officials of the social security system to bring about better coverage for homebased workers. At the grassroots level, homebased workers' groups have been helped to organize and to gain access to existing resources such as local economic development programs, training for enterprise development and sometimes credit.
Helping groups market their products has also been an important PATAMABA function. The organization has set up display counters in the capital city, Manila, organized exhibitions, and obtained export orders for its members. It is now affiliated with an NGO marketing program called MAGIC and is exploring the possibility of developing a South-to-South marketing network.

The success of PATAMABA, and other homeworkers' associations in Thailand and Indonesia, has led the ILO to propose a new project that would expand this work to other parts of Asia. The new project will expand coverage to five countries, with organizing carried out along the same lines as PATAMABA and SEWA.

Antonina Nina is the national coordinator of PATAMABA and a former homebased garment worker. She started sewing when she was 15 and soon begin doing piece-rate work. After subtracting the cost of thread and rental of a sewing machine, she was earning only a few pesos a week.

"After a while, I got involved with $\mathrm{KaBaPa}$ and began to understand how pitiful our situation was. I got cheated by a contractor who refused to give me my payment so, after this

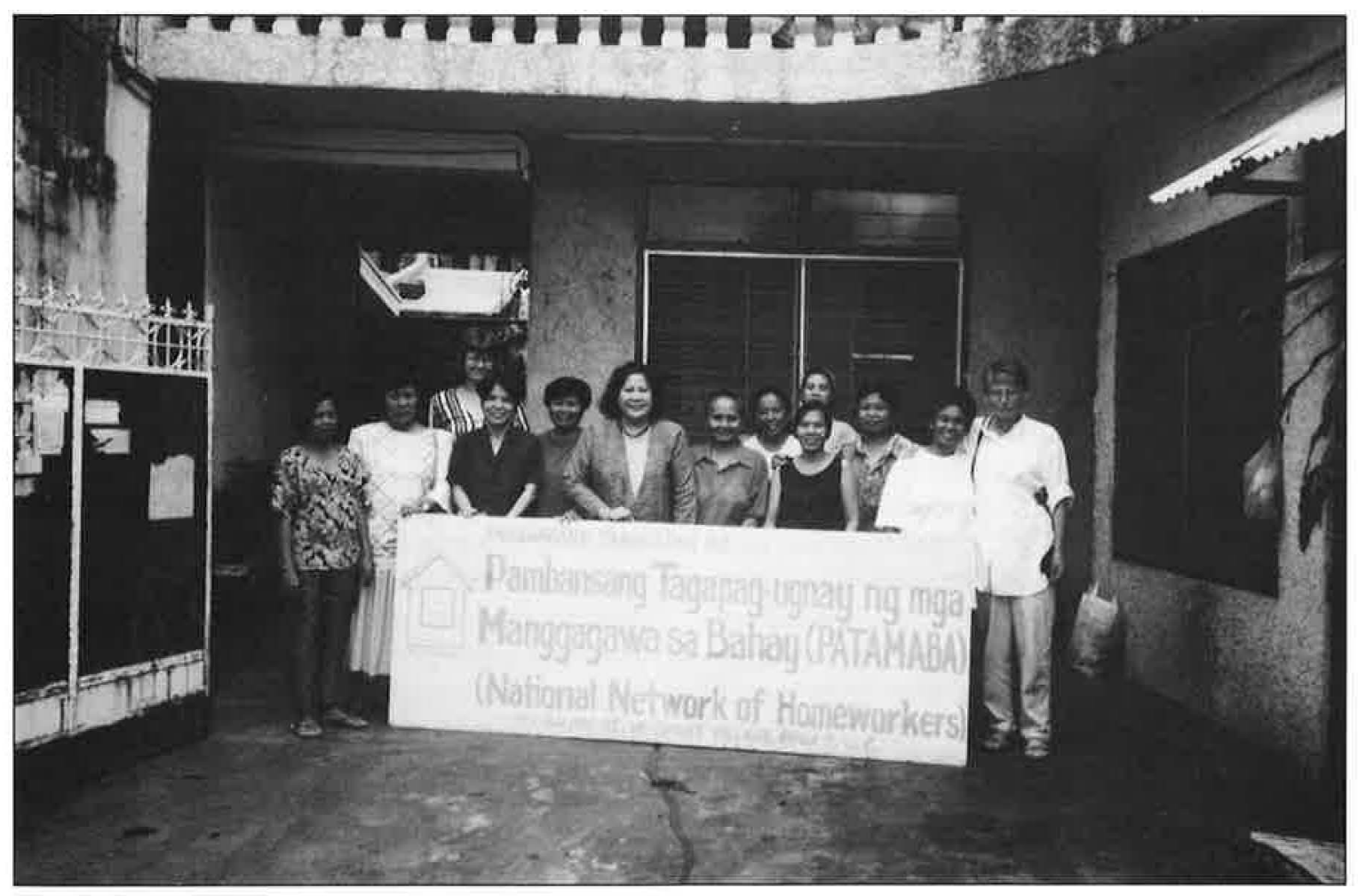


experience, I shifted to another contractor. I also thought of requesting her to give me a written document stating when I would be paid and how much the payment for sewing the material would be. Other workers thought this was a good idea. They requested me to be their leader and to help them get prompt payment and better rates."

In 1987, these homebased workers formed a stitchers' cooperative, but they were not able to reach enough markets to keep going. Antonina continued to organize the stitchers and to negotiate with contractors on their behalf, so it wasn't long before her own contractor stopped giving her work. "At first I felt sad and hurt because what l earned from sewing had helped my family a lot," she recalls. "Then I decided to focus my energies on fulltime organizing.

"I believe that it is only through an organization that homebased workers can attain social protection. Together, we can bargain for higher wages. We can ask for social security, for assistance when we give birth or when we get sick due to our work. We can have more education and training. I experienced a lot of pain because of my lack of formal schooling. I would not like the young homebased workers to experience the same pain.

It is difficult to be a leader in an organization. I do not expect material gain or personal happiness as a reward for my involvement. All I want is change in the condition of homebased workers. That would be like giving me a crown."

\section{The Homebased Workers' Association, Toronto, Canada}

The International Ladies' Garment Workers' Union (ILGWU) has been organizing workers in the garment industry across North America since 1905, but most of its experience has been with factory workers. However, beginning in the 1980s, here too there has been a shift in production away from factories and a rise in the number of homebased workers. Recognizing the growth in this sector, the ILGWU local in Toronto, the Ontario District Council, decided to take up the challenge of organizing this illusive work force.

The first step was to find out just who the homeworkers are, and then to learn the de- tails about their pay and working conditions. In 1991, the Council completed its first study which showed that the majority of homeworkers were women from immigrant groups who had little choice other than to take up homework because of the lack of childcare. Many of them had previous experience working in factories.

Here as elsewhere, homeworkers are paid on a piece-rate basis. The majority report that their pay is determined solely by the employer and most is below the statutory minimum wage of the Province of Ontario. Some of the workers surveyed earned only one-third of the minimum wage; one worker earned less than one-sixth. In addition to the exploitation of these women, their low wages undercut standards in unionized factories, and even many non-unionized shops, thus contributing to the downward spiral of working conditions in the entire clothing sector.

Based on this information, the Council decided to start a campaign to organize homeworkers and create public awareness about conditions in the clothing industry. A Coalition for Fair Wages and Working Conditions was launched with the objectives of winning public support and seeking legislative change by educating officials from the various political parties in Ontario to the extent of homework in the province.

While the Coalition found support from a broad range of community organizations-in particular, women's organizations and church groups-it considered the organizing of homeworkers themselves as its most essential task. A union is legally entitled to act on behalf of workers in collective bargaining only when union membership reaches a certain percentage of workers in, for instance, a factory. It is, therefore, very difficult for a union to establish a legal basis for representing homeworkers. The ILGWU established an associate membership scheme for homeworkers called the Home Workers Association (HWA). Associate membership is a way around these legal restrictions, and has been used with other previously unorganized workers such as flower sellers in New York. As a result of their membership in this more formal structure, homeworkers themselves are able to speak out at legislative hearings on labor law reform.

The HWA studied experiences elsewhere, particularly in the UK, and used a lot of 


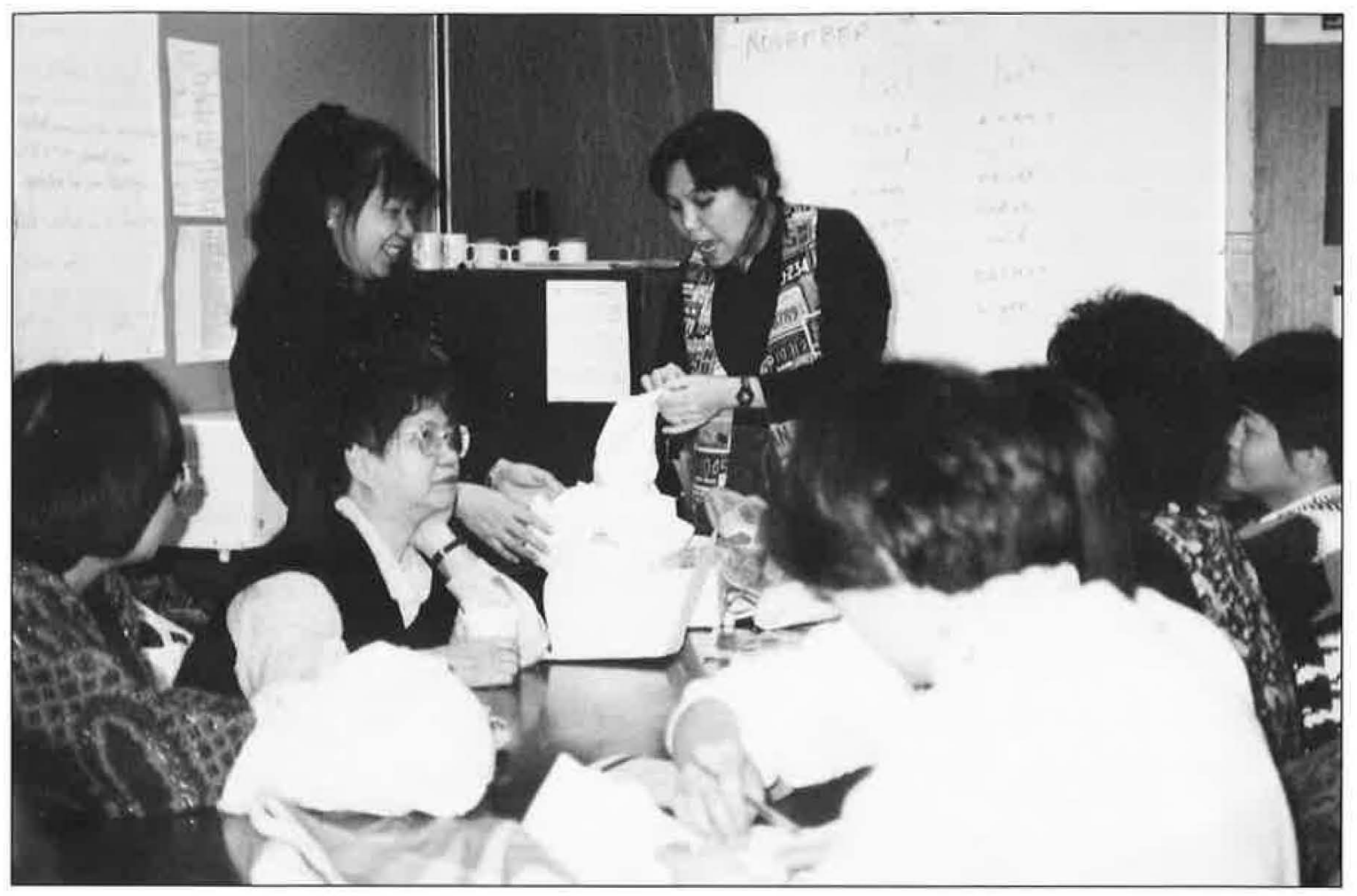

those methods to reach Canadian homeworkers (telephone helpline, social events, employing organizers from minority communities, etc.) but adapted them to operate within the framework of a regular union. Another strategy was to focus public attention on particular retailers who sell expensive garments made by homeworkers for illegal wages and often under appalling conditions. Other unions joined forces with HWA, such as the Public Sector Alliance of Canada (PSAC), thus bringing together those organizing around the oldest form of homeworking-clothing - and those concerned with the growth of its newest form - teleworking.

As many homeworkers are immigrants, the lack of a common language compounds their isolation and complicates organizing. Thus, the HWA has initially concentrated on recruiting Chinese-speaking homeworkers and thus far has organized over 100 Chinese women working in this sector. It is extremely difficult, if not impossible to contact women homeworkers from minority communities without employing outreach workers who share a similar background, culture and language. This is not just a language issue but also has to do with understanding the community. Both in the UK and Canada, the immediate employer may share a similar background with the home- workers, thus creating a common bond while "outsiders" would be seen as interfering and not to be trusted.

In its first year, the HWA recruited over one hundred women through a combination of personal contacts, social activities, legal advice, and training workshops. Most of the homeworkers signed up again after their first year's membership. Here it is important to note that the numbers of homeworkers involved in industrialized countries are much smaller than in Asia. Thus organizing one hundred homeworkers in a Canadian city is a considerable achievement even if the actual numbers are small when compared with what has been achieved in Asia. Over time, the union aims to expand organizing to other ethnocultural groups and perhaps to homeworkers in other sectors.

The HWA is also seeking changes in the law in the Province of Ontario that would allow homeworkers to join a union of their own choice and would give that union collective bargaining rights on behalf of these workers. (Current legislation in Ontario does not allow homeworkers to join a trade union if they work for more than one employer.) At present, the HWA is based in Toronto and operates very much as part of the ILGWU. Historically there has been a reluctance on the part of trade unions 
to engage in this form of organizing. While part of the reason is the difficulty in reaching, let alone organizing these workers, the reality is that unions have tended to view homework as threatening to the gains that have been made on behalf of industrial workers. However, there is increased recognition among labor organizations that this is a growing sector of the work force that appears to be here to stay.

Even though it regards the HWA as a trade union initiative, the ILGWU has recognized that traditional trade union approaches alone are unlikely to be effective when dealing with homeworkers. The union has realized the need to make a long-term commitment to this kind of organizing because not only does it lack a strong local base in this area, but the women also have little or no experience with trade unions. Yet this cadre of workers is one that is in desperate need of assistance in organizing for fair wages, decent working conditions and access to social services.

\section{Self Employed Women's Union, Durban, South Africa}

Sophie Lamani is 59 years old and lives in a shack in one of the townships surrounding the city of Durban, South Africa with her two grandchildren. Everyday she begins sewing as soon as her grandchildren leave for school and she has cleaned the house. As there is no electricity in her shack, she uses a hand powered machine; only in summer, when it stays light longer, can she work late in the evening.

Ms. Lamani sells the clothes she makes from her home. Every weekend she puts up a stand at the bus terminal and, once a year, she travels to the Transkei (her rural homeland) to sell her wares there. Ms. Lamani does not have a problem selling what she produces; her problem is that she does not always have enough money to buy fabric. To make ends meet, she also needs to do housecleaning twice a week.

Asked if she would rather be working full time than sewing at home, Ms. Lamani replies, "Well one would always prefer being employed full-time, but even if I got a job I would still continue to sew. I am not educated and not young anymore. Whatever job I could get would be as a domestic worker and those kind of jobs don't pay well enough for one to survive."

The Self Employed Women's Union (SEWU) was launched in Durban, in 1994. Based on the SEWA model-South African organizers visited Ahmedabad and, subsequently, a team from SEWA made a return visit to Durban-within two years membership has grown to 1,500 members in 25 localities.

SEWU's first activity was a study of homebased workers in the cities of Durban and Cape Town. They found that, as with their counterparts in India, homebased work was indeed widespread. Sixty-nine percent of randomly selected households surveyed included at least one homebased worker. However, unlike India, only three percent of the workers were piecerated; the others were all own-account workers.

As South Africa is a multi-racial society, it is not surprising that homebased workers in African, colored and Indian households had different characteristics. African women, having less access to the formal sector, were more likely (71 percent) to work at home. Among the other groups, men and women were equally represented.

SEWU's aims are to:

- Build unity between women whose productive and subsistence work is not recognized.

- Develop negotiating skills so that women can negotiate directly with the city council, police, small contractors and middle-men, civic and political organizations, through their own elected representatives.

- Assist with legal advice.

- Assist women to solve problems of child care, credit, lack of maternity, sick or disability benefits.

- Develop lobbying skills so that women can organize to get laws changed if they are not suitable to their needs.

- Develop leadership skills among women who work outside the formal sector.

- Provide access for women to: skills training, credit and loan facilities, legal assistance, health advice and assistance, and relief or counselling for survivors of violent attacks including rape. 


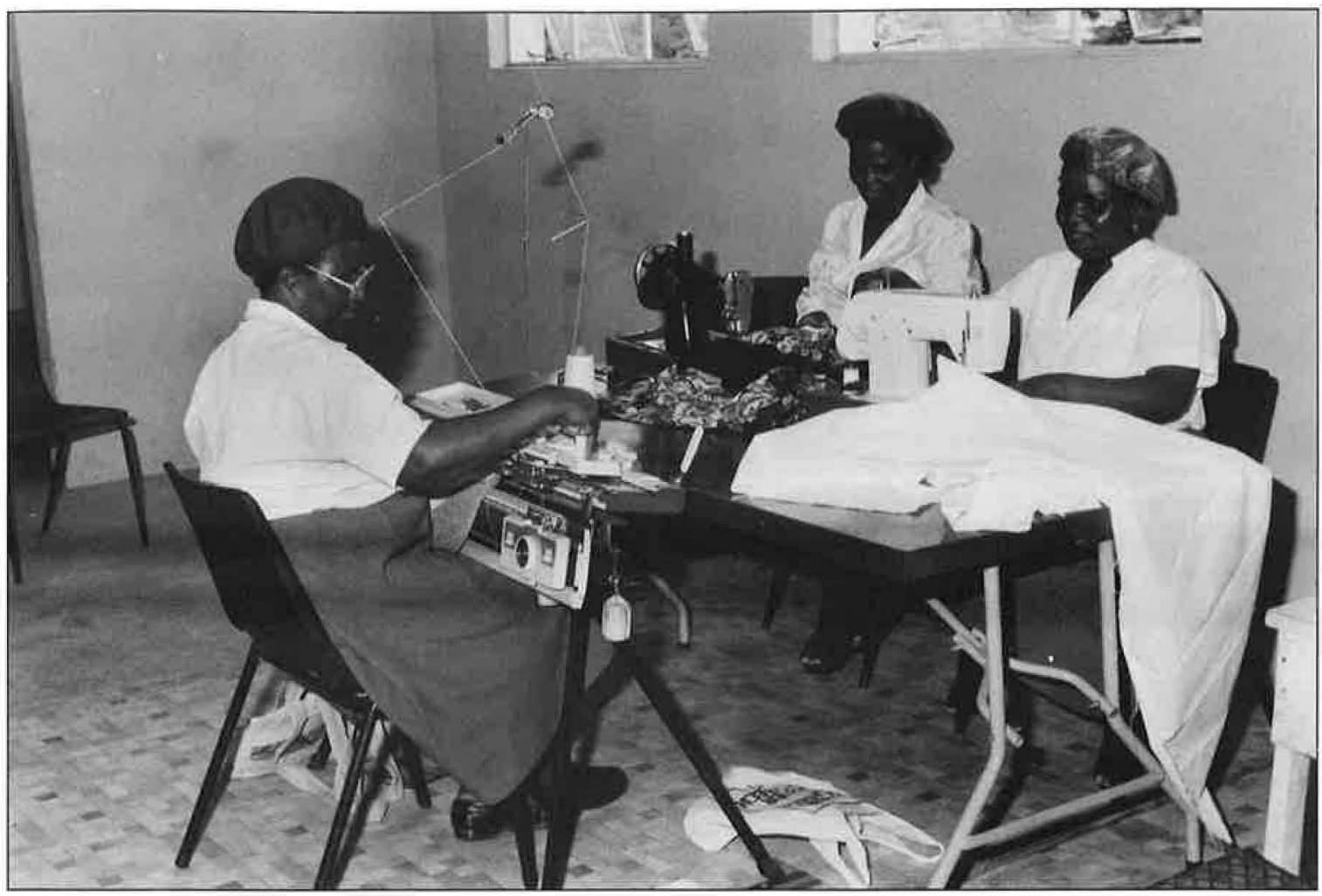

SEWU's main activities during its first year focused on organizational development through meetings, leadership workshops and skills development classes. Its first members were women street vendors who were facing problems of harassment from the police and city authorities. Following SEWA's example, the union is seeking ways to link its members with available means of credit and thus far 120 women have benefited by taking out loans. SEWU has also been able to provide a creche for the children of its members.

Like SEWA, SEWU is a women-only organization and it is a union representing women workers. It seeks to make clear that within the informal sector, just as in the formal sector, there are employers and there are workers. And the workers-who are predominantly female-suffer exploitation from a variety of sources including suppliers, unscrupulous entrepreneurs, corrupt public servants who control their access to resources, as well as racketeers. For this reason, SEWU believes that workers in the informal sector have an even greater need for union representation than those employed in the formal sector.

In addition, because patriarchal relationships are dominant in the informal sector, those in control are primarily men and those under control are women. It is for that reason that SEWU is a trade union for women only. As one member recently remarked: "It is the women who are suffering the most. We are the ones who carry the responsibility. Our children come to us when they are hungry, not to their fathers. If men want a union, they can form their own."13

\section{THE INTERNATIONAL MOVEMENT}

\section{The Growth of Networks}

As described above, over the past twenty years, homebased workers in a variety of settings have begun to get organized and to make their voices heard. Now, all over the world, groups and unions are organizing, conducting research and bringing to light issues of mutual concern. These groups and unionsand homebased workers themselves-have recognized, both individually and collectively, that across all borders they have much in common, are many in number, and have a lot to learn from one another. The various groups and unions working with homebased workers be- 


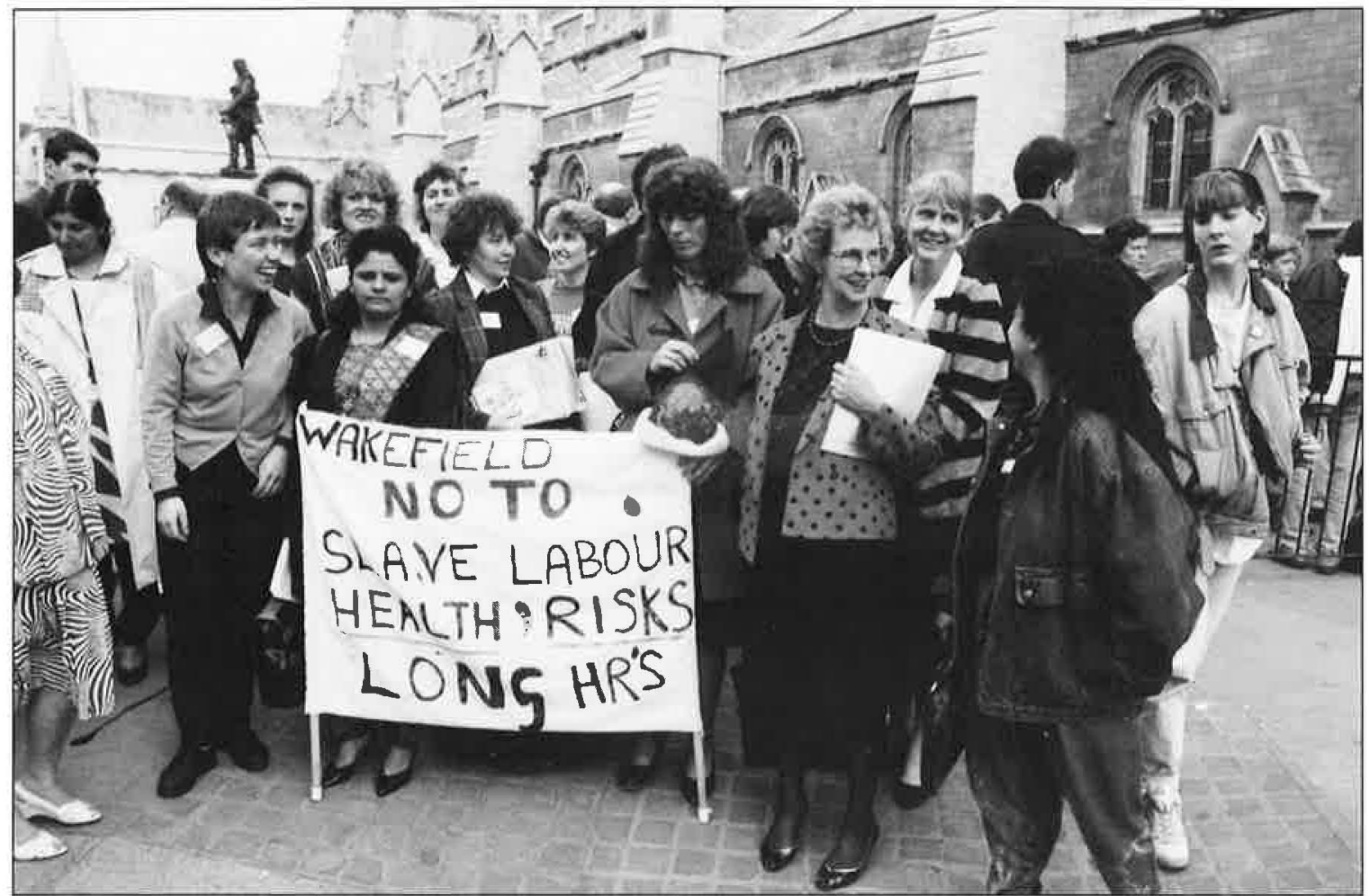

gan forging linkages in the early 1980s. At first, as noted in the previous section, these were across countries in the same region of the world - South East Asia and SEWA; the UK, the Netherlands and Portugal--with groups working at the grassroots level offering one another practical assistance, information, and encouragement.

In Asia, field visits by women to programs in other countries proved to be a particularly effective method of cross-fertilization. For example, group leaders from several women's craft cooperatives in Northern Thailand participated in a study tour to SEWA in India. One group leader, a bamboo and rattan worker, saw how SEWA helped its members plan social security, savings, and insurance schemes. When she returned to Thailand, she explained to her fellow cooperative members how these operated and together they decided to work on establishing similar schemes themselves.

As these regional networks developed, they helped individual organizations exchange experience; to learn and draw inspiration from each other. Within Europe, the European Homeworking Group was set up in 1994 to build more formal links between those working with homebased workers in different European countries. Most members of the group are from trade unions; others are from homebased worker projects, independent organizations and church groups

Other cross-regional field visits and contacts also proved fruitful. Most notably, perhaps, the Self-Employed Women's Union (SEWU) in South Africa was established after some of its founders visited India to get a firsthand view of SEWA's work. Similarly, when the International Ladies Garment Workers' Union (ILGWU) realized the need to organize homebased workers in Canada, they first looked into the methods used in England, incorporating many of those strategies in the design of their own campaign.

Ultimately these linkages have led to campaigns for recognition and protection at both the national and international level. An important, but informal, mechanism for establishing these linkages was to hold international workshops and conferences on homebased workers. For example, SEWA organized a panel on homebased workers at the Third World Conference on Women in Nairobi in 1985 as well as a conference on homebased workers in India in the late 1980s.

Then in 1990, in the Netherlands, homeworkers and those active with homeworkers from both developing and developed coun- 
tries, as well as researchers and representatives from international bodies, met for the first time to discuss the whole issue of homework, including how to draw up legislation (both national and international) to improve wages and working conditions. In fact, how to coordinate campaigns to lobby for such legislation was the main item of discussion at the Netherlands conference.

In 1991, with the help of the Holdeen India Fund, SEWA brought together people from trade unions, homeworkers' organizations, and researchers at the biannual conference of the Association for Women in Development. It was there, in Washington, D.C., that the founding of an international network was discussed. A more formal international network was established at a subsequent meeting in Belgium in 1994. At that meeting, all the organizations working with homeworkers came together to form an international network and to plan an international campaign in preparation for the International Labour Organisation's annual conference to be held in June 1995, and the Fourth World Conference on Women to be held in Beijing in September 1995. The international network was registered in the Netherlands as a formal trust to be known as HomeNet.

For the first two years, the headquarters of HomeNet has been located in England as the network's focus in 1995-96 is on the ILO. After the ILO campaign is over, while the focus may change, the network will go on. The headquarters will then be shifted to the developing world, probably somewhere in Asia, and work will continue in support of the organization's primary objective - the international campaign to make homebased workers visible, to recognize their contribution to the economy, and to help them gain the legal protection extended to other sectors of the labor movement.

\section{The ILO Recognizes Homeworkers}

The International Labour Organisation is the specialized agency of the United Nations which deals with employment issues and sets standards for international labor laws. It is a tripartite body whose decisions are made by representatives of governments, employers and trade unions. In the past, the standards set by the ILO have mainly applied to the for- mal labor sector: that is, to workers in largescale, organized industries. In fact over the last century, trade unions in industrialized countries (and their counterparts or affiliates in developing countries) have fought for bans on homework, seeing it as a threat to organized labor. Not surprisingly, the ILO has followed the stance of its member trade unions and, until recently, has: a) seen homework as a form of cheap labor that is intrinsically exploitative and homeworkers as too dispersed to be organized; and b) resisted recognizing homeworkers much less giving them official status in ILO deliberations.

For the past twenty years, SEWA has fought a long, hard campaign through official trade union channels for the recognition of homebased workers and for their inclusion in the debates and programs of the ILO. As the number of groups and unions working with homeworkers has increased, the strength of the SEWA-led campaign has also increased. Largely due to this campaign, the official policies on homework of both the ILO and the international trade union movement have shifted. Many trade unions now advocate the organization of homeworkers and their inclusion in union membership. As a culmination of this remarkable shift in policy, in June 1996, the annual conference of ILO member states is going to vote on an international convention on homeworkers drafted by a tripartite committee of the organization.

\section{The ILO Convention}

Because they have the power of international law, ILO conventions have to be broad and flexible enough to be applied in different countries. Thus the process by which the ILO reaches a decision on a convention by its very nature has to be long and technical. Following an initial agreement within the ILO Governing Body on its importance, the Office of the ILO submits a proposal in draft form. This proposal, after extensive consultation with governments, becomes the basis for discussion and voting as part of a technical committee meeting held during the ILO's annual conference. The next and final step is for a full vote to be taken at a plenary session during the ILO's annual conference the following year. The entire process involved in reaching this step can take several years. 


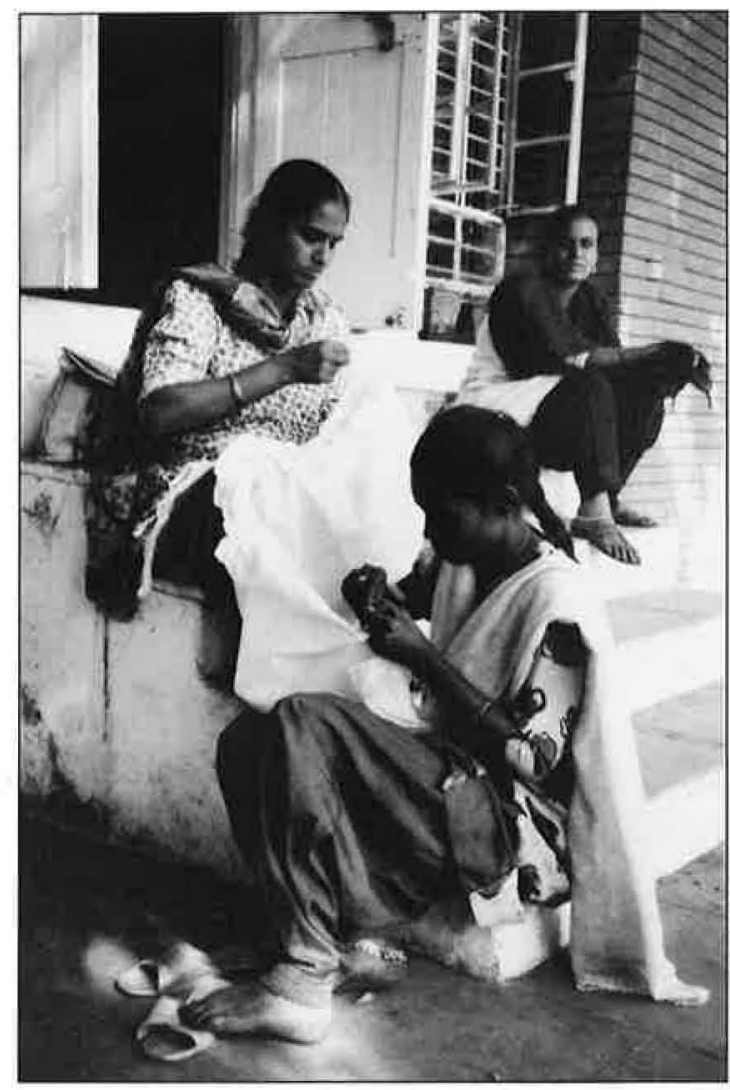

In the case of the proposed homeworkers convention, the process started in 1990. Under pressure from the SEWA-led international campaign, the ILO convened an Expert Meeting on the conditions of homeworkers. The participants in that tripartite discussion did not agree on the need for an international standard on homework and recommended that the ILO Governing Body weigh the significance of the issue. In late 1993, the Governing Body agreed to put homework on the agenda for discussion on international standard setting.

This could not have come about without trade union support-particularly from among the international trade unions. The International Union of Foodworkers (IUF) was the first to take up the issue of homework and it has supported the struggle for a Convention wholeheartedly in all forums. The International Confederation of Free Trades Unions (ICFTU) passed a resolution in support of Homebased Workers in 1988. The ICFTU plays a major role at the ILO and was primarily responsible for the issue coming up for debate. The International Textiles, Garments and Leather Workers Federation (ITGLWF) probably has the greatest num- bers of homeworkers within its sector and has also given its support.

At the 1995 ILO conference, a special technical committee made up of representatives of employers, government and workers recommended (by a narrow margin) that an international standard should be drafted and forwarded for a vote during the 1996 ILO conference. Following this decision, the committee went on to consider the proposed text of the convention. The text of the Convention is relatively short and covers basic points such as: equality of treatment with other workers; the right to a minimum wage; social security protection; maternity benefits; health and safety provision; protection against discrimination and the right to organize. It also includes some wider measures such as the inclusion of homeworkers in labor statistics; the need for a system of labor inspection and for regulation of intermediaries; programs of support for advice, training and organization of homeworkers.

During the committee's deliberations, the employers' organizations voted as a bloc against regulation arguing that homework is too diverse a phenomenon to be regulated by one text, that regulation would inhibit creation of employment and that homeworkers are covered by existing regulation in many countries. Whereas (in a reversal of their traditional stance), the trade unions countered these arguments at every point arguing that there is enough data on homework and enough exploitation against homeworkers to justify legislation. The governments, on the other hand, expressed a range of opinions; the European Union countries are strongly in favor of the Convention, with the exception of Germany and the United Kingdom.

The outcome of the two weeks of debates over the draft convention in 1995 was a vote in favor of the Convention (backed by a Recommendation) within the Committee. The Committee's report was accepted in the plenary session of the Conference. The final vote, after another round of detailed debate, will be taken at the June 1996 ILO Conference. For the proposed international standard to be passed, a two-thirds majority of all members of the ILO is needed. Given the unanimous support of trade unions for the Convention and the unanimous opposition of the employers' organizations, the deciding vote will ultimately be cast by member governments. 
Since their narrow victory in June 1995, SEWA and other member organizations participating in the international campaign have continued to raise the visibility of homeworkers and stress the need for an international standard on homework. They have lobbied governments, publicized the issue, and informed the public. Most importantly, of course, they have continued to organize homeworkers to ensure that their voices are heard.

The vote in Geneva, in June 1996, can have an impact on the living and working conditions of millions of homeworkers, in countries all over the world, both industrialized and developing, and urban and rural areas. Yet even if the Conference adopts the international Convention, only half the battle will have been won! If the Convention on homework is passed, it would, like other ILO conventions, have the status of an international treaty and member states of the ILO would then decide whether to ratify the treaty by "signing" it. So member governments will still have to be lobbied to ensure that they first ratify the standard and then take the measures necessary to ensure that its provisions are translated into national law and policy.

Ratification of the Convention by member states will not automatically improve the pay and working conditions of homeworkers, but it will set an international standard for minimum pay and working conditions as well as providing them with recognition as workers who are entitled to a fair return for their labor. Member governments will then have to be pressured to translate the provisions of the treaty into national law and policy.

But even then, homeworkers will still have to be organized to ensure that they actually receive the protection laid down by national law. Better still, they should be involved in the process of implementing the law; for example, ensuring that local institutions (trade unions and tripartite boards) are set up or restructured to provide them with representation.

When the legislation is implemented, it should change the whole face of the labor movement given the sheer size of the unorganized (or informal) sector which is much larger than the organized (or formal) sector in developing countries and is growing rapidly in developed countries. It could also bring unorganized workers, the majority of whom are women, into unions in large numbers for the first time-perhaps surpassing the number of people previously organized. And with their entry, the concerns and issues raised by labor unions will inevitably change. The women's movement too will be affected as the consciousness of large numbers of hitherto marginalized women will be raised. Finally, it can be a powerful means to reduce poverty among homeworkers, who are among the poorest of all workers.

\section{Notes}

1. This section draws heavily on information from Gisela Schneider de Villegas, 1990, "Home work: A Case for Social Protection," International Labour Review, 129(4): 423-439. Prugl, Elisabeth "Women and Homework," submitted for publication in the Encyclopedia of Third World Women, Nell Stromquist, Ed. (New York: Garland Publishing); and Tai Lok Lui, 1994. Wage Work at Home: The Social Organization of Industrial Outwork in Hong Kong, (Avebury Publishing Group, Hants, UK).

2. Conditions of Work Digest, Home Work Volume 8, 2/1989, ILO, Geneva).

3. Council of Europe. 1989. The Protection of Persons Working at Home, a report prepared by the Study Group of the 1987/88 Coordinated Social Research Programme, Stasbourg, Germany.

4. Rose, Kalima. 1992. Where Women Are leaders: The SEWA Movement in India, London: Zed Books,

5. Prugl, Elisabeth. Forthcoming. "Women and Homework" submitted for publication in the Encyclopedia of Third World Women, Nell Stromquist, Ed, (New York: Garland Publishing Inc.).

6. Crummentt, Maria de los Angeles. 1988. "Rural Women and Industrial Homework in Latin America." World Employment Programme Research Working Paper. Geneva: International Labor Organization.

7. Prugl, Elisabeth. Forthcoming.

8. The European Homeworking Group Report, 1995, is an unpublished report of the group's activities, written by Jane Tate as coordinator of the group. It was based on information collected at a meeting of the group held in Funchal, Madeira, April 1995

9. Jhabvala, Renana, Rahima Shaikh and SEWA Academy Team. 1995. Wage Fixation for Home-Based Piece Rate Workers. (Ahmedabad: SEWA Academy)

10. Textile, Clothing and Foorwear Union of Australia (TCFUA) 1995. The Hidden Cost of Fashion: Report on the National Outwork Information Campaign. Carlton, Victoria, Australia.

11. Rose, Kalima. 1992.

12. Rose, Kalima. 1992.

13. Horn, Pat. 1995. "Empowering union," Sash. 37(2): 25-26. 


\section{Where to Contact HomeNet}

\section{South Asia}

Self Employed Women's Association SEWA Reception Centre

Opp. Victoria Garden

Bhadra, Ahmedabad 380001

India

Tel: $\quad 91795506477$

91795506444

Fax: 91795506446

\section{South East Asia}

Lucy Lazo

ILO Regional Office

GPO Box 1759

Bangkok 10501

Thailand

Tel: 6622882238

6622882237

Fax: 6622881019

\section{Africa}

Self-Employed Women's Union P.O. Box 48621

Qualbert 4078

South Africa

Tel: 27313043042

Fax: 27313043719

\section{The Americas}

UNITE

25 Cecil Street, 2nd Floor

Toronto, Ontario M5T 1N1

Canada

Tel: 14169771384

Fax: 14169776999

\section{Europe}

Jane Tate

24 Harlech Terrace

Leeds LS11 7DX

United Kingdom

Tel: 441132701119

Fax: 441132773269

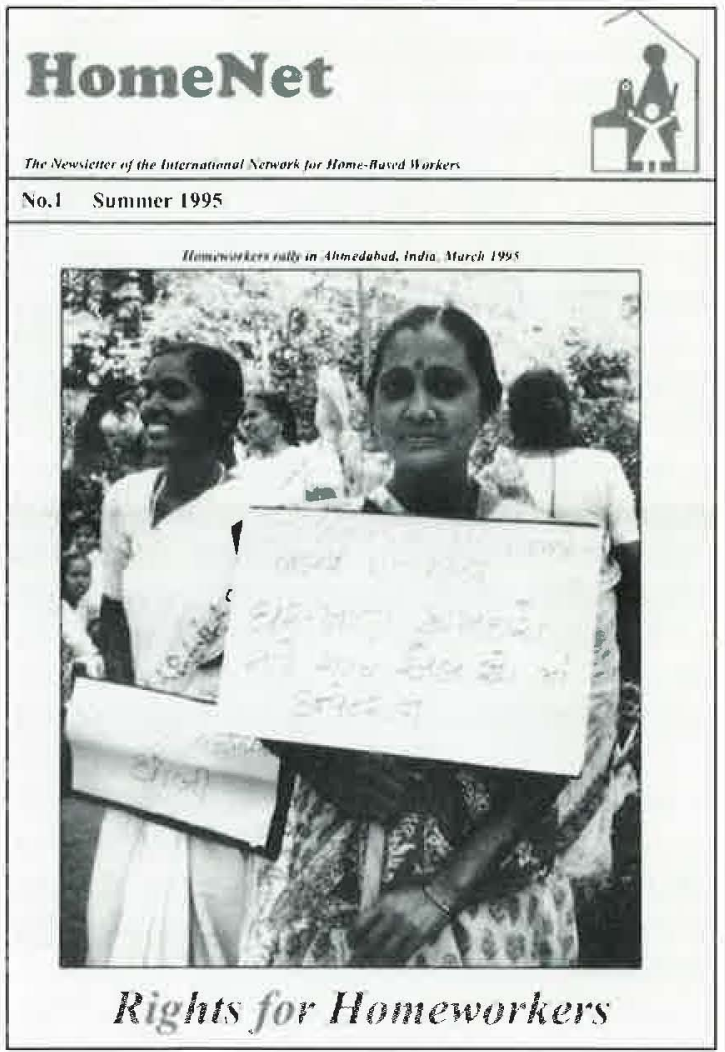

Back copies of HomeNet Newsletters 1,2 and 3 are still available. The HomeNet bulletin is available in English, French and Spanish. The leaflet of the European Group is now available in English, French, Spanish, Portuguese, German and Italian. If you would like copies of any of these publications, contact the UK office of HomeNet. 
Design: Ann Leonard

Photos: HomeNet

Typography: Heidi Neurauter-Orth

Printing: $\quad$ Graphic Impressions

\section{Other Editions of SEEDS Currently Available}

No. 2 Hanover Street: An Experiment to Train Women in Welding and Carpentry -Jamaica (English, Spanish)

No. 3 Market Women's Cooperatives: Giving Women CreditNicaragua (Spanish, French)

No. 4 Women and Handicrafts: Myth and Reality-International (English, Spanish, French)

No. 5 The Markala Cooperative: A New Approach to Traditional Economic Roles-Mali (French)

No. 6 The Working Women's Forum: Organizing for Credit and Change-India (English, French)

No. 7 Developing Non-Craft Employment for Women in Bangladesh (English, French, Spanish)

No. $8 r$

No. 9

No. 10

$\begin{array}{lll} & \text { HQ } & \text { Jhabvala. Renana. } \\ \text { No.11 } & 1870.9 \quad \begin{array}{l}\text { Out of the shadows } \\ \text { No.12 }\end{array} & \text { no.18 }\end{array}$

No. 13 POPULATION COUNCIL LIBRARY

No. 14 NEW YORK

No. 15

No. 16

GAYLORD S in: Ine SAKIHI Experience (tnglish, French)

No. 17 Supporting Women Farmers in the Green Zones of Mozambique (English)

If you would like additional copies of this issue or any of the editions of SEEDS listed above, please write to us at the address given below. Copies of selected SEEDS issues in local languages are currently being published by organizations in the following countries: Egypt, India, Indonesia, Kenya, Nepal, Pakistan, Thailand and Vietnam. Please write to us for more information if you are interested in these materials.

Ann Leonard, Editor

SEEDS

P.O. Box 3923

Grand Central Station

New York, New York 10163, U.S.A. 


\section{9}

1

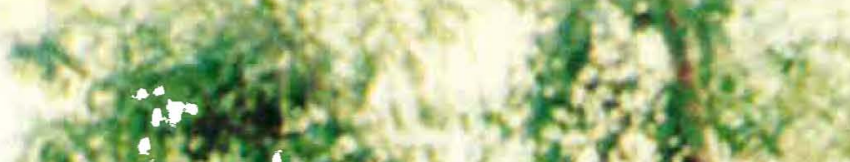

acon

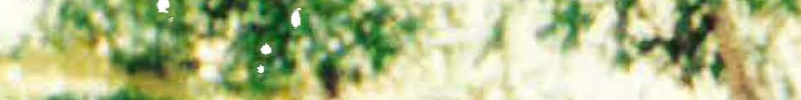

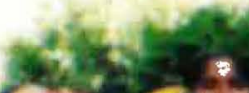

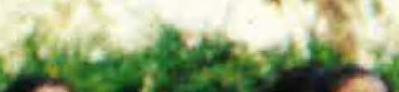

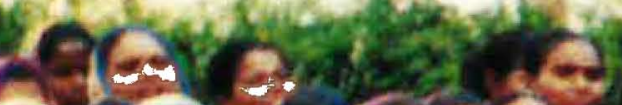

(i)

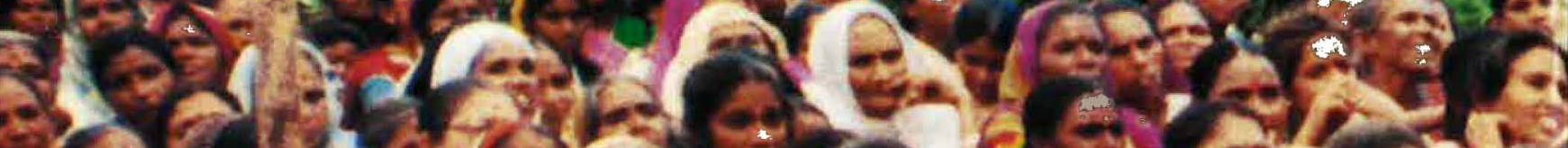

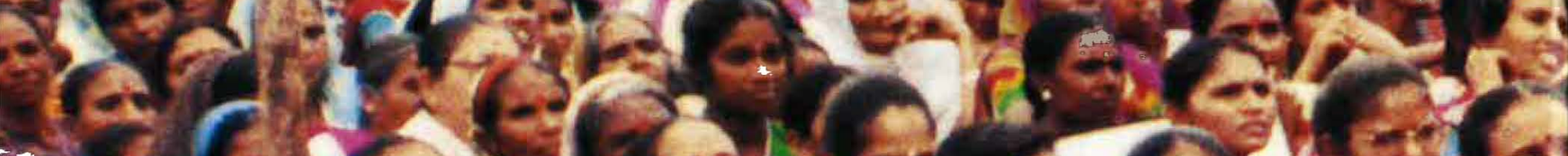

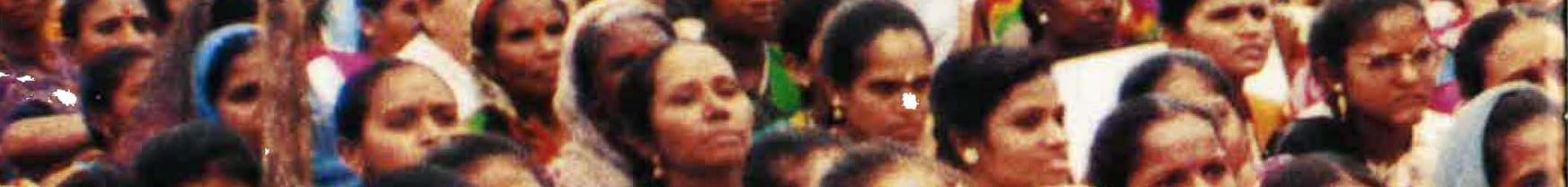

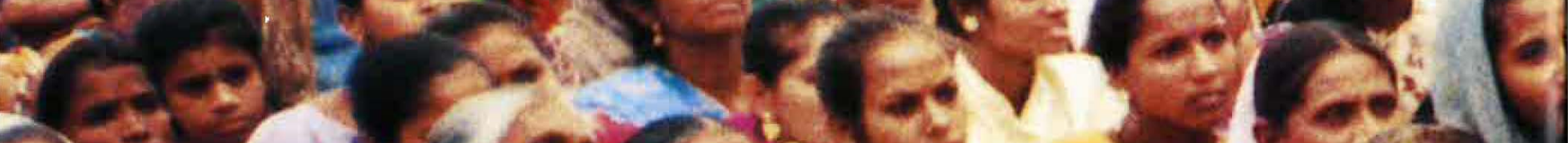

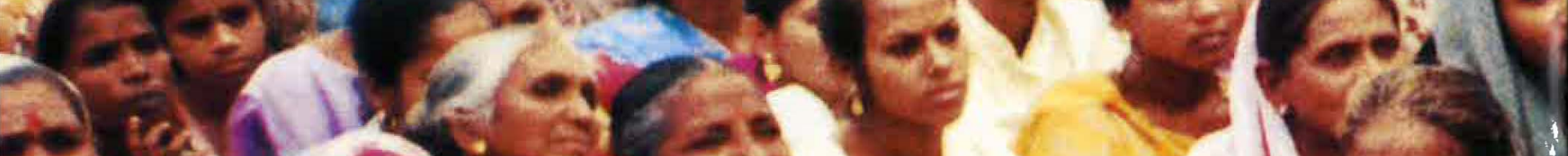
$\Leftrightarrow x^{2} \cdot 1$.

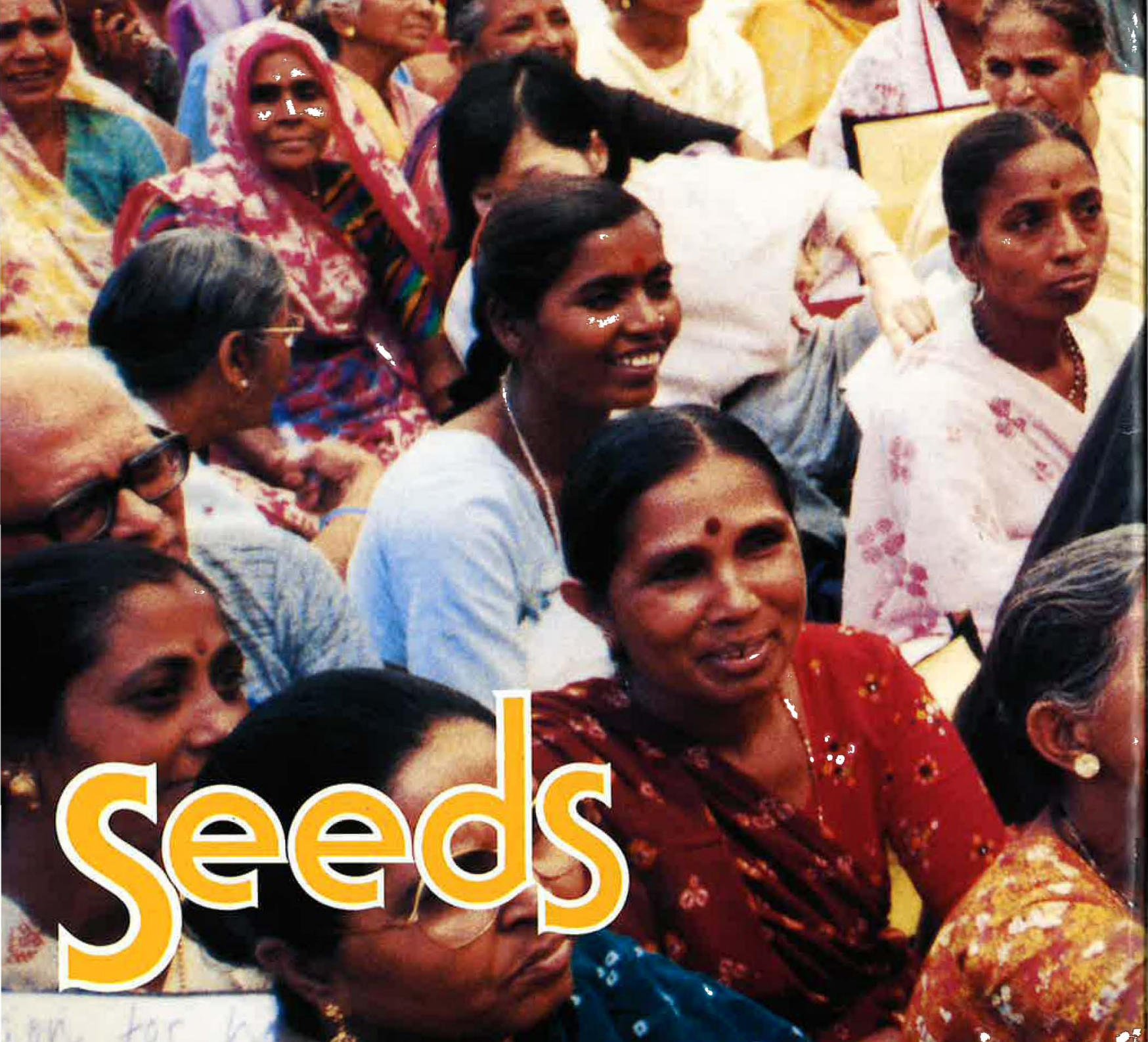

